\title{
Glycinergic Synapses in the Rod Pathway of the Rat Retina: Cone Bipolar Cells Express the $\alpha 1$ Subunit of the Glycine Receptor
}

\author{
Marco Sassoè-Pognetto, ${ }^{a}$ Heinz Wässle, and Ulrike Grünert \\ Max-Planck-Institut für Hirnforschung, Neuroanatomische Abteilung, D-60528 Frankfurt am Main, Germany
}

\begin{abstract}
Glycine receptors (GlyRs) and their role in retinal circuitry were analyzed immunocytochemically in the rat retina. Specific antibodies against the $\alpha 1$ subunit of the GlyR and against the GlyR-associated protein gephyrin, respectively, were used. In the inner plexiform layer (IPL), both antibodies produced a punctate label that was shown by electron microscopy to occur at synapses. Gephyrin-like immunoreactivity (-LI) was more widely distributed, indicating that gephyrin might also occur at nonglycinergic synapses. At the ultrastructural level, gephyrin-LI was found at the cytoplasmic face of postsynaptic membranes of amacrine and ganglion cells, but was never detected in bipolar cell axons. Immunoreactivity for the $\alpha 1$ subunit was concentrated in the cleft of conventional synapses made by amacrine cell processes onto ganglion cell dendrites and cone bipolar axons. The latter synapses differ from other glycinergic synapses since they are not labeled by the antibody against gephyrin used in this study. In order to identify the type of bipolar cell involved in these synapses, the distribution of the $\alpha 1$ subunit was compared with that of recoverin-immunoreactive cone bipolar cells and with that of parvalbumin-immunoreactive All-amacrine cells. Double-label immunofluorescence showed that, in the outer part of the IPL, $75 \%$ of the $\alpha 1$ immunoreactive puncta were colocalized with recoverinpositive bipolar cell axons and $71 \%$ of the $\alpha 1$-immunoreactive puncta were colocalized with parvalbumin-positive All-amacrine processes. Hence, the $\alpha 1$ subunit of the GlyR is present at the chemical synapses established by All-amacrine cells with OFF-cone bipolar cells and OFF-ganglion cells. These synapses play a key role in the transmission of scotopic signals through the OFF-channel of the rod pathway.
\end{abstract}

[Key words: glycine receptor, $\alpha 1$ subunit, gephyrin, rat retina, cone bipolar cell, All-amacrine cell, rod pathway, recoverin, parvalbumin, immunocytochemistry, electron microscopyl

\footnotetext{
Received Nov. 10, 1993; revised Feb. 23, 1994; accepted Mar. 2, 1994.

We express our gratitude to Dr. H. Betz, Dr. K. W. Koch, and Dr. C. C. Stichel for providing the antibodies. We also thank G. S. Nam, W. Hofer, U. Pieper, and F. Boij for excellent technical assistance, and I. Odenthal for typing the manuscript. We are grateful to Dr. J. Kirsch for valuable discussion and to Dr. W. Rowland Taylor for reading and improving the manuscript. This study was supported by a grant from the Deutsche Forschungsgemeinschaft (SFB 269, B4).

Correspondence should be addressed to Ulrike Grünert, Max-Planck-Institut für Hirnforschung, Deutschordenstrasse 46, D-60528 Frankfurt am Main, Germany.

Present address: Dipartimento di Anatomia e Fisiologia Umana, Corso Mas simo d'Azeglio 52, I-10126 Torino, Italy.

Copyright (C) 1994 Society for Neuroscience $0270-6474 / 94 / 145131-16 \$ 05.00 / 0$
}

It is well established that glycine acts as a major inhibitory transmitter in the mammalian retina (reviewed by Massey and Redburn, 1987; Marc, 1989; Pourcho and Goebel, 1990; Vaney, 1990; Wässle and Boycott, 1991). Autoradiographic localization of neurons that accumulate ${ }^{3} \mathrm{H}$-glycine and immunocytochemical studies has shown that glycine-containing neurons include approximately half of the amacrine cell population and some cone bipolar cells (Pourcho and Goebel, 1985a, 1987a; Wässle et al., 1986). The best-characterized glycinergic amacrine cell of the mammalian retina is the AII-amacrine cell, which plays a key role in the conduction of scotopic signals (Wässle et al.. 1991). In the scotopic pathway of the mammalian retina, rods are conncctcd to rod bipolar cells, but instead of these synapsing directly onto ganglion cells, AII-amacrine cells are interposed. AII-amacrine cells make glycinergic chemical synapses with OFFcone bipolar cells and OFF-ganglion cells and contact ON-cone bipolar cells via large gap junctions (Famiglietti and Kolb, 1975; Sterling, 1983; Strettoi et al., 1992; Chun et al., 1993).

The neurotransmitter glycine mediates inhibition through aclivation of a ligand-gated chloride channel that is antagonized by the alkaloid strychnine (reviewed by Langosch et al., 1990; Betz, 1992). The glycine receptor (GlyR) purified from the mammalian spinal cord (Pfeiffer et al., 1982; Graham et al., 1985) is composed of three ligand-binding subunits of $48 \mathrm{kDa}(\alpha)$ and two homologous polypeptides of $58 \mathrm{kDa}(\beta)$ that span the postsynaptic membrane in a pentameric arrangement to form a chloride-selective channel (Langosch et al., 1990; Betz, 1991). So far, at least three different $\alpha$-subunit variants $(\alpha 1, \alpha 2, \alpha 3)$ of the GlyR have been identified (Grenningloh et al., 1987, 1990; Kuhse et al., 1990a,b). These isoforms are developmentally regulated (Becker et al., 1988; Hoch et al., 1989; Malosio et al., 1991 a) and modify the pharmacological and electrophysiological properties of the GlyR (Schmieden et al., 1989; Sontheimer et al., 1989; Grenningloh et al., 1990; Kuhse et al., 1990a,b; Bormann et al., 1993). Homo-oligomeric $\alpha 2$ receptors have a low strychnine-binding affinity and are considered to represent a neonatal form of GlyR, which is replaced during development by receptors containing the $\alpha$ l subunit (Becker et al., 1988; Hoch et al., 1989; Malosio et al., 1991 a; Bormann et al., 1993). Adult GlyRs are predominantly composed of $\alpha 1$ and $\beta$ subunits, the $\alpha 3$ subunit being expressed at low levels in only a few brain regions (Malosio et al., $1991 \mathrm{a}$ ).

A peripheral membrane protein of $93 \mathrm{kDa}$, which copurifies with the mammalian GlyR upon affinity chromatography (Pfeiffer et al., 1982; Graham et al., 1985), has been shown to be associated with cytoplasmic domains of the GlyR complex (Schmitt et al., 1987). This protein, named gephyrin, can bind with high affinity to polymerized tubulin and has been proposed 
to anchor the receptor in the postsynaptic membrane by interaction with subsynaptic tubulin (Betz et al., 1991; Kirsch et al., 1991).

Monoclonal antibodies ( $\mathrm{mAbs}$ ) have been raised against the affinity-purified GlyR protein (Pfeiffer et al., 1984). Two of them ( $\mathrm{mAb} 2 \mathrm{~b}$ and $\mathrm{mAb} 7 \mathrm{a}$ ), used in this study, react with a single component of the receptor complex, the $48 \mathrm{kDa}(\alpha 1)$ subunit and the $93 \mathrm{kDa}$ protein gephyrin, respectively (Schröder et al., 1991; Kirsch and Betz, 1993). A third antibody (mAb 4a), which recognizes all of the $\alpha$ subunits known to date and the $\beta$ subunit (Schröder et al., 1991), was not used. Immunohistochemical studies with these $\mathrm{mAbs}$ have revealed the localization of GlyR subunits and of gephyrin in many regions of the CNS (Triller et al., 1985, 1987; Altschuler et al., 1986; Araki et al., 1988; Basbaum, 1988; van den Pol and Gorcs, 1988; Wenthold et al., 1988; Naas et al., 1991; Chen and Hillman, 1993; Mitchell et al., 1993). In most of these studies, $m A b$ 7a, specific for gephyrin, has been used as a marker for GlyRs. Recently, however, it has become evident that gephyrin is more widely distributed than previously reported and can be expressed independently of the GlyR $\alpha$ subunits (Kirsch and Betz, 1993; Kirsch et al., [993a). This finding has raised the possibility that gephyrin might be associated with neurotransmitter receptors other than the GlyR (Kirsch and Betz, 1993).

Little is known about the distribution of GlyRs in the vertebrate retina. Gephyrin-like immunoreactivity (-LI) has been examined using both light and electron microscopy in some species (Jäger and Wässle, 1987; Smiley and Yazulla, 1990; Pourcho and Owczarzak, 1991b; Yazulla and Studholme, 199 la,b; Zucker and Ehinger, 1992, 1993; Grünert and Wässle, 1993). In cat and monkey retinas, electron microscopic investigations have shown that gephyrin-LI is clustered at sites postsynaptic to amacrine cells (Pourcho and Owczarzak, 1991b; Grünert and Wässle, 1993). Only recently, mAbs 2b and 4a, directed against the transmembrane components of the GlyR, have been applicd to scctions of the mammalian retina (Grüncrt and Wässle, 1993), but the identity of the cell types stained by these antibodies is still unclear.

A major unsolved problem concerning the distribution of GlyRs in the mammalian retina is the absence of gephyrin-LI from the axons of bipolar cells (Pourcho and Owczarzak, 1991b; Grünert and Wässle, 1993), despite the fact that these neurons receive inpul from glycinergic amacrine cells (Marc and Liu, 1985; Hendrickson et al., 1988; Pourcho and Owczarzak, 1991a; for rat: Chun et al., 1993) and have been demonstrated by electrophysiological studies to possess glycine-gated chloride channels (Karschin and Wässle, 1990; Suzuki et al., 1990). A possible explanation for the failure to detect gephyrin staining within bipolar cell axons in the inner plexiform layer (IPL) is that these retinal neurons could express an alternative form of the GlyR that is not recognized by $\mathrm{mAb} 7 \mathrm{a}$ (Pourcho and Owczarzak, 1991b; Grünert and Wässle, 1993). The lack of gephyrin-LI is especially intriguing at the glycinergic synapse between AII-amacrine cells and OFF-cone bipolar cells.

In order to address this problem and to provide new insights into the role of GlyRs in retinal circuitry, we have further investigated the distribution of GlyRs in the rat retina. Using electron microscopy, we show that the $\alpha 1$ subunit is expressed by bipolar cells mainly at conventional synapses from presumed AII-amacrine cells. In contrast, bipolar cell axons seem not to contain the $93 \mathrm{kDa}$ polypeptide gephyrin. Using double-labeling immunocytochemistry and light microscopy, we show (1) that in the outer part of the IPL the $\alpha 1$ subunit is present on the axons of cone bipolar cells, which are stained by an antiserum against recoverin (Milam et al., 1993); and (2) that the $\alpha 1$ subunit occurs at synapses made by parvalbumin-immunoreactive AII-amacrine cells (Wässle et al., 1993). This suggests that the $\alpha 1$ subunit of the GlyR plays a key role in the synaptic transmission from AII-amacrine cells into the OFF-channel. In addition, the results indicate that the $93 \mathrm{kDa}$ polypeptide gephyrin is not necessarily expressed at all glycinergic synapses.

\section{Materials and Methods}

Antibodies. Two mAbs raised against the purified GlyR were used in the present study. Their preparation and specificity have been described in detail previously (Pfeiffer et al., 1984; Schmitt et al., 1987; Schröder et al., 1991). Briefly, mAb $2 b$ (kindly provided by Dr. H. Betz, Dept. of Neurochemistry, Max-Planck-Institut für Hirnforschung, Frankfurt, Germany) recognizes a single band of $48 \mathrm{kDa}$ on Western blots of purified GlyR preparations (Pfeiffer et al., 1984) and has been shown to be specific for the N-terminal 10 residues of the $\alpha 1$ subunit (Schröder et al., 1991). The mAb 2b recognizes a sequence of the $\alpha 1$ polypeptide, which is highly variable among different GlyR subunits. This explains the selectivity of this antibody for the $\alpha 1$ subunit. Monoclonal antibody 7a (purchased from Boehringer, Mannheim, Germany) is specific for the $93 \mathrm{kDa}$ protein gephyrin (Pfeiffer et al., 1984) and does not crossreact with any of the other GlyR polypeptides (Schmitt et al., 1987). The antibodies were used diluted 1:100 (mAb 2b) or 1:50 (mAb 7a).

Two polyclonal antisera directed against calcium-binding proteins were also used. The anti-recoverin serum (kindly provided by Dr. $\mathrm{K}$. W. Koch, Institut für Biologische Informationsverarbeitung, Jülich, Germany) was raised in rabbit against recoverin from bovine rod outer segments (Lambrecht and Koch, 1992) and was used at a dilution of 1:4000. Antibodies against recoverin have recently been shown to label two subpopulations of cone bipolar cells as well as photoreceptors of the rat retina (Milam et al., 1993). The anti-parvalbumin (PV) serum was raised in rabbit against cat PV (Stichel et al., 1986) and was used at a dilution of 1:1000. In the rat retina, this antiserum labels the AIIamacrine cell in addition to a wide-field amacrine cell (Wässle et al., 1993).

The following secondary antisera were used: goat anti-mouse conjugated to CY3 (carboxymethylindocyanine; Dianova, Hamburg, Germany; 1:1000); goat anti-rabbit conjugated to FITC (fluorescein isothiocyanate; Dianova; 1:50); sheep anti-mouse conjugated to biotin (Amersham, Braunschweig, Germany; 1:100) in combination with either streptavidin-Texas red (Amersham; 1:100) or extravidin-horseradish peroxidase (Sigma, Deisenhofen, Germany; 1:100).

Light microscopic immunocytochemistry. Adult albino rats were deeply anesthetized with halothane and decapitated. The eyes were enucleated and opened by an encircling cut along the ora serrata. The vitreous was removed and the posterior eyecup was fixed for 20 or $30 \mathrm{~min}$ in freshly prepared $4 \%$ paraformaldehyde in phosphate buffer $(\mathrm{PB} 0.1 \mathrm{M}$, pH 7.4). After several rinses in PB containing 5\% sucrose, the eyecup was cryoprotected by immersion in ascending sucrose concentrations $(10 \%, 20 \%, 30 \%)$. The retina was then dissected out of the eyecup and cut with a cryostat in $12-\mu \mathrm{m}$-thick vertical sections, that were collected on gelatin-coated slides. The immunocytochemical labeling was carried out using the indirect immunofluorescence method, as described previously (Grüncrt and Wässlc, 1993). Briefly, after blocking in 10\% normal goat serum (NGS, in $0.01 \mathrm{~m}$ phosphate-buffered saline, PBS, containing $0.5 \%$ Triton $X-100$ ), the sections were incubated overnight in the primary antibodies diluted in PBS with $3 \%$ NGS, $0.5 \%$ Triton X-100, and $0.05 \%$ sodium azide. The sections were then rinsed in PBS $(3 \times$ $10 \mathrm{~min}$ ), incubated for $1 \mathrm{hr}$ in the secondary antiserum (diluted in PBS with $3 \%$ NGS and $0.5 \%$ Triton .X-100), and rinsed again in PBS $(3 \times$ $10 \mathrm{~min})$. Finally, the sections were coverslipped with either glycerol or Mowiol (Hoechst, Frankfurt, Germany; see Harlow and Lane, 1988) and observed under epifluorescence in a Zeiss photomicroscope (Axiophot). Control sections were processed omitting the first antibody. This procedure always resulted in a complete lack of immunoreactivity.

Double immunolabeling was performed by incubating the sections in a mixture of one of the polyclonal antisera, anti-recoverin, or anti-PV, respectively, and $m A b 2 b$. The binding sitcs of the primary antibodies were revealed by anti-rabbit IgG conjugated to FITC (green fluores- 

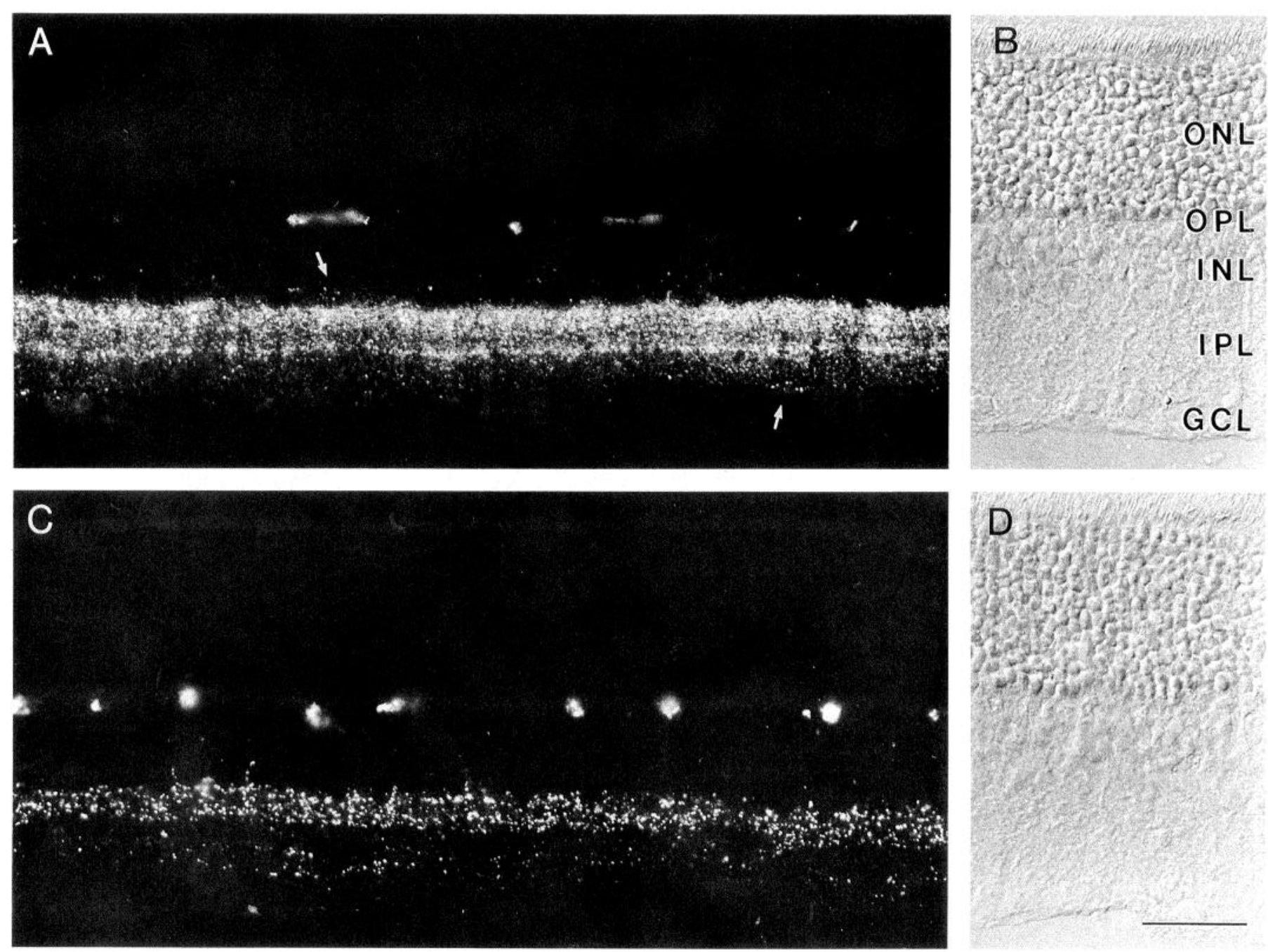

Figure 1. $A$ and $C$ are micrographs of consecutive vertical sections through a rat retina labeled with $\mathrm{mAbs} 7 \mathrm{a}$ and $2 \mathrm{~b}$ and processed with the immunofluorescence method (secondary antiserum conjugated to CY3). $B$ and $D$ are Nomarski micrographs of the sections shown in $A$ and $C$ to illustrate the layers of the retina. The section in $A$ was processed for gephyrin-LI. Fine punctate labeling is distributed throughout the inner plexiform layer $(I P L)$ and two more intensely labeled bands can be distinguished. One relatively broad band is situated in the outer part of the IPL, while a more narrow band is just below the middle of the IPL. Single-labeled puncta are visible on some cell bodies (arrows) in the inner nuclear layer $(I N L)$ and in the ganglion cell layer $(G(L)$. The section in $C$ shows immunoreactivity for the $\alpha 1$ subunit of the GlyR. Two bands of punctate labeling are visible in the outer and in the inner part of the IPL, respectively. The outer band is more intensely labeled. Note that compared to gephyrin-LI, the density of labeling is much lower and the punctate elements are considerably larger. Some blood vessels show unspecific fluorescence in the outer plexiform layer $(O P L)$. $O N L$, outer nuclear layer. Scale bar, $35 \mu \mathrm{m}$.

cence) and anti-mouse IgG conjugated to either Texas red or CY3 (red fluorescence). Controls were prepared by omitting the incubation with one of the two primary antibodies and in this case only one immunoreactivity could be specifically detected. In some instances, very strong CY3 fluorescence was also visible with the green filter (leakage). When Texas red instead of $\mathrm{CY} 3$ was used no leakage of the red fluorescence through the green filter was observed. All double-labeling experiments were therefore performed with $\mathrm{CY} 3$ as well as with Texas red to make sure that leakage of the red fluorescence does not cause false colocalization.

Photomicrographs of the double-immunolabeled sections were taken on color reversal film (Kodak, Ektachrome $400 \mathrm{X}$ ) using a $63 \times$ objective and green or red fluorescence. The slides were projected onto a drawing table, and the bipolar cells, AII-amacrine cells, and GlyR-immunoreactive puncta were drawn at a final magnification of $1250 \times$. The drawings were copied onto transparent acetate sheets, so they could be superimposed, and brought into register (see Figs. 9, 10). The total number of GlyR-immunoreactive puncta and the number of puncta that coincide with recoverin-immunoreactive bipolar cell axons, or with PV-immunoreactive AII-cell processes, were counted. The percentage of puncta that coincided was calculated and the mean $( \pm S D)$ of three independent estimates (the three authors) is presented. The IPL was subdivided into five strata of approximately equal width. The outer two strata (the OFF-sublamina) and the inner three strata (the ON-sublamina) were analyzed separately.

Electron microscopic immunocytochemistry. The eyecups were fixed by immersion in $4 \%$ paraformaldehyde and $0.05 \%$ glutaraldehyde for $10 \mathrm{~min}$, followed by an additional $20 \mathrm{~min}$ fixation in $4 \%$ paraformaldehyde in PB containing $0.2 \%$ picric acid, $0.2 \%$ of a $0.5 \mathrm{~m}$ calcium chloride solution, and $0.2 \%$ of a $0.5 \mathrm{~m}$ magnesium chloride solution. After cryoprotection in $30 \%$ sucrose, small pieces of retina were repeatedly frozen with liquid nitrogen and thawed, in order to enhance antibody penetration. They were then embedded in agar and cut with a vibratome in $70-\mu$ m-thick vertical sections. The sections were collected in cold PBS and processed free floating, using the avidin-biotinperoxidase method (Hsu et al., 1981). The antibodies were diluted in the same dilution media used for light microscopy, but Triton X-100 was omitted from all solutions. After blocking in 10\% NGS, the sections were incubated in the primary antibody for $4 \mathrm{~d}$ at room temperature. Thereafter, the sections were rinsed in PBS $(4 \times 10 \mathrm{~min})$ and incubated 

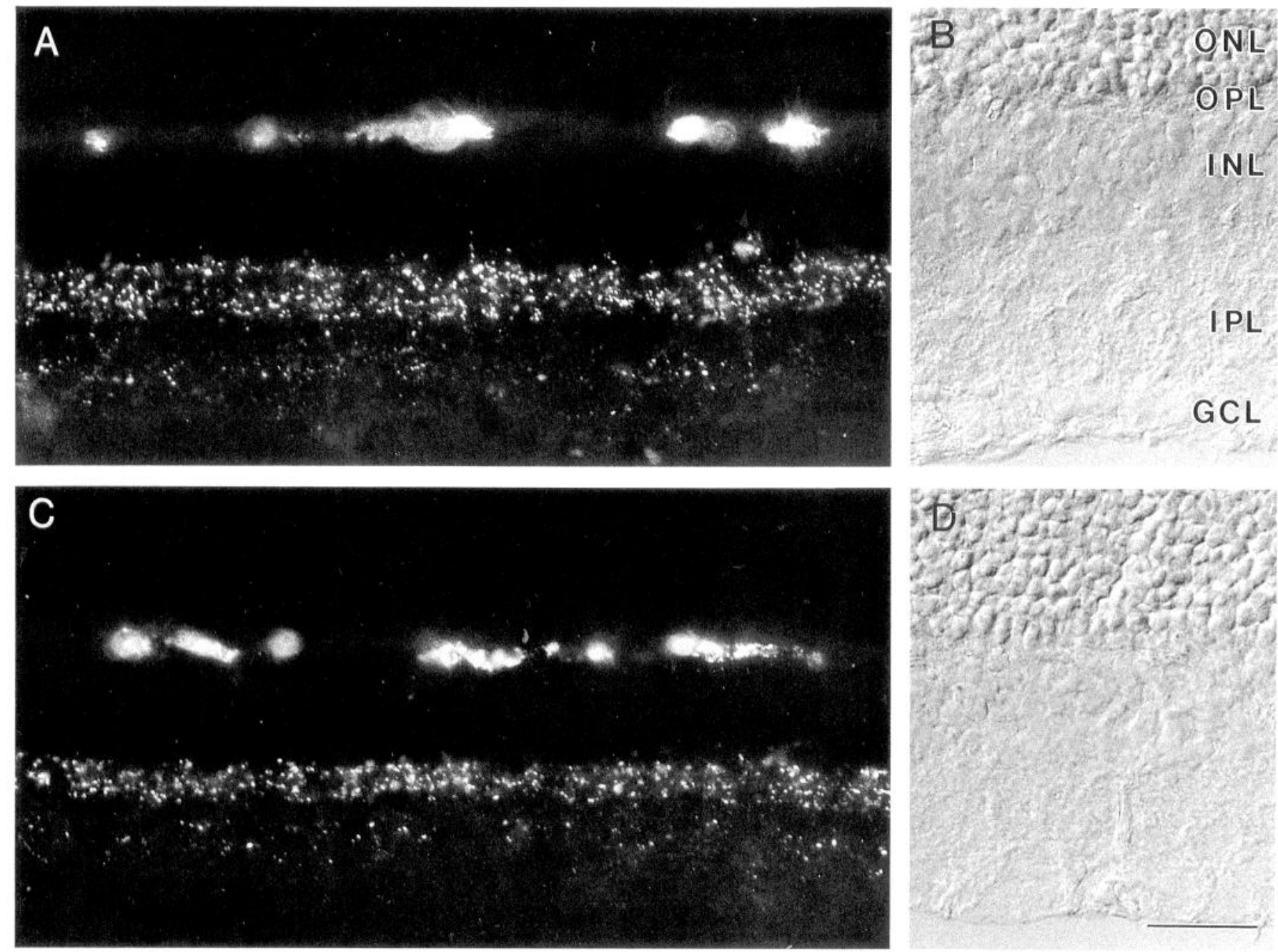

Figure 2. Micrographs of vertical sections through a rat retina immunostained for the $\alpha 1$ subunit of the GlyR (secondary antiserum conjugated to $C Y 3$ ). $A$ and $C$ are sections from the upper and lower retina, respectively, at comparable eccentricities. $B$ and $D$ are Nomarski micrographs of the sections. Note that the immunoreactivity for the $\alpha 1$ subunit is more prominent in the upper retina $(A)$ than in the lower retina $(C)$. Abbreviations are as in Figure 1. Scale bar, $25 \mu \mathrm{m}$.

for $2 \mathrm{hr}$ at room temperature in the biotinylated secondary antiserum, rinsed again in PBS $(4 \times 10 \mathrm{~min})$, and transferred to a solution containing the extravidin-horseradish peroxidase complex for $1 \mathrm{hr}$. After rinses in PBS and in $0.05 \mathrm{M}$ Tris- $\mathrm{HCl}(\mathrm{pH} \mathrm{7.6)}$, the sections were reacted in $3,3^{\prime}$-diaminobenzidine $(0.05 \%$ DAB in Tris- $\mathrm{HCl}, \mathrm{pH} 7.6$ ) with $0.01 \%$ $\mathrm{H}_{2} \mathrm{O}_{2}$ for $10 \mathrm{~min}$. Subsequently, the sections were rinsed in Tris- $\mathrm{HCl}$ and then in $0.1 \mathrm{M}$ cacodylate buffer ( $\mathrm{pH} 7.4)$, postfixed in glutaraldehyde ( $2.5 \%$ in cacodylate buffer) for $2 \mathrm{hr}$ at $4^{\circ} \mathrm{C}$, and washed in cacodylate buffer at $4^{\circ} \mathrm{C}$ overnight. The DAB reaction product was silver intensified by incubating the sections in a solution containing $2.6 \%$ hexamethylenetetramine (Merck, Darmstadt, Germany), $0.2 \%$ silver nitrate (Merck), and $0.2 \%$ disodium tetraborate (Merck) for $10 \mathrm{~min}$ at $60^{\circ} \mathrm{C}$. The sections were then rinsed in distilled water and treated for 2 min with gold chloride $(0.05 \%$ in distilled water; Merck). Finally, the sections were rinsed in distilled water and incubated for $2 \mathrm{~min}$ in sodium thiosulfate ( $2.5 \%$ in distilled water, Merck). The sections were then postfixed with $2 \% \mathrm{OsO}_{4}$ in cacodylate buffer for $1 \mathrm{hr}$, dehydrated in a graded series of acetone (30-100\%), and flat-embedded in Epon 812 (Serva, Heidelberg, Germany). Serial ultrathin sections were cut and then stained with uranyl acetate and lead citrate and examined in a Zeiss EM10 electron microscope. Counts of labeled synaptic profiles were made directly in the electron microscope. subdividing the IPL into an outer region (corresponding to the first two strata) and an inner region (corresponding to strata 3-5).

\section{Results}

Immunocytochemical labeling with mAb $7 a$ (gephyrin) and $m A b 2 b$ ( $\alpha$ l subunit)

Both $\mathrm{mAbs} 7 \mathrm{a}$ and $2 \mathrm{~b}$ produced a strong labeling that was characterized by a distinct punctate appearance in the IPL (Fig. 1). Punctate labeling was also detected in the outer plexiform layer (OPL); this immunoreactivity could be well differentiated from unspecific fluorescence corresponding to blood vessels, but was very sparse and is not visible in Figures 1 and 2. Consistent with previous findings (Grünert and Wässle, 1993), gephyrinLI was found to be distributed throughout the IPL, with evidence of a stratification in two more intensely labeled bands (Fig. 1 $A$ ). A broad labeled band was located in the outer third of the IPL, corresponding to the OFF-sublamina (Famiglietti and Kolb, 1976; for rat: Famiglietti and Vaughn, 1981; Peichl, 1989); the other band was located slightly below the middle of the IPL. In addition, gephyrin-immunoreactive puncta outlined some cell bodies in the inner part of the inner nuclear layer (INL) and in the ganglion cell layer (GCL) (arrows in Fig. 1A). 

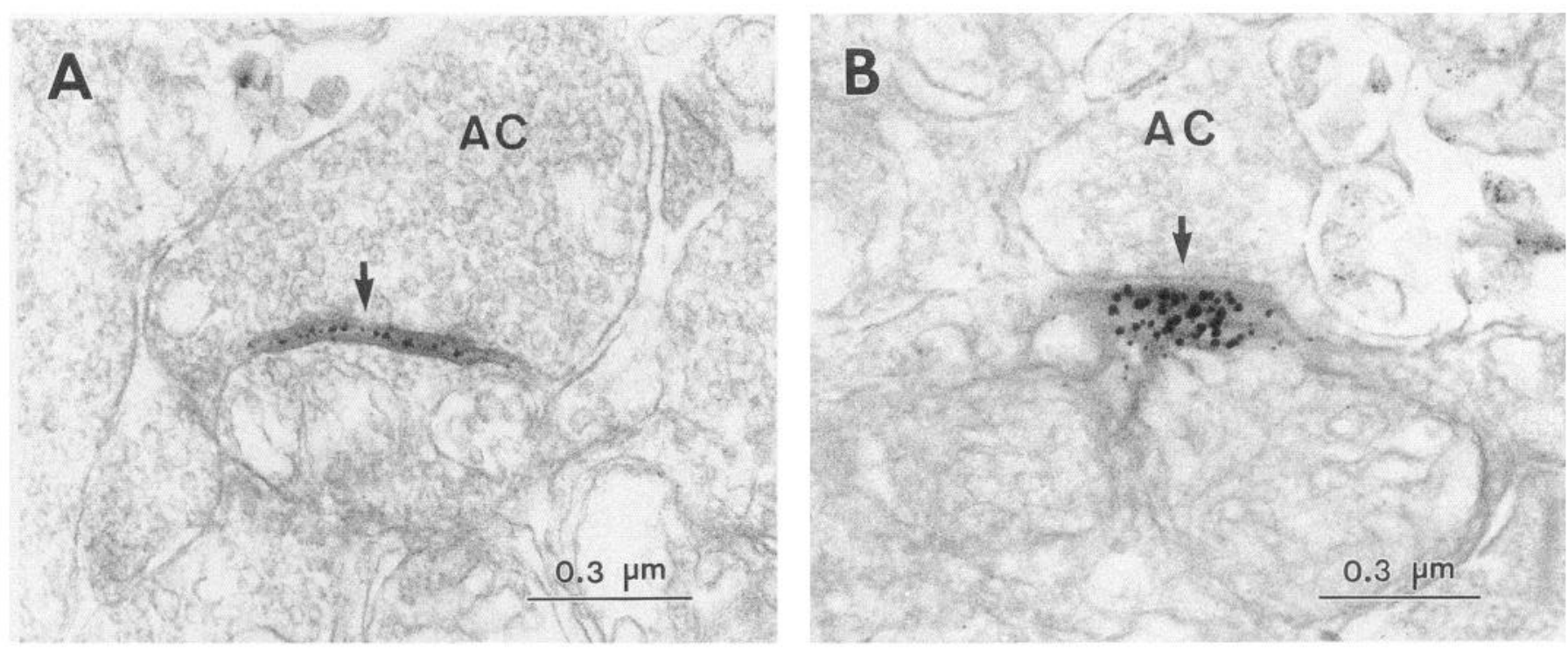

Figure 3. Electron micrographs showing the ultrastructural localization of the $\alpha 1$ subunit of the GlyR and of gephyrin, respectively, at conventional synapses in the IPL. The peroxidase reaction product was silver intensified, treated with one cycle of gold chloride toning, and therefore appears as particles of irregular shape and size. $A$. An amacrine process $(A C)$ is presynaptic at an $\alpha 1$-immunopositive contact (arrow) in stratum 1 of the IPL. The immunoreactivity is concentrated in the synaptic cleft. $B$, A small amacrine process $(A C)$ makes a synapse (arrow) with a gephyrinpositive element in the innermost part of the IPL. Gephyrin-LI is restricted to the cytoplasmic face of the postsynaptic membrane.

Immunoreactivity for the $\alpha 1$ subunit was also characterized by a broad band in strata 1 and 2 and more sparse labeling in the inner half of the IPL (Fig. 1C). At some locations, the outer band appeared to be subdivided into two thinner laminae containing a higher density of punctate structures. When compared with gephyrin-LI, the labeling pattern obtained with $\mathrm{mAb} 2 \mathrm{~b}$ appeared more restricted. The puncta immunoreactive for the $\alpha 1$ subunit were of two distinct diameters: larger puncta were preferentially located in the outer band, while smaller puncta were present in the outer as well as in the inner band. In gephyrin-labeled sections such large puncta were never observed. The density of punctate labeling obtained with $\mathrm{mAb} 2 \mathrm{~b}$ was higher in the upper retina when compared with lower retina (compare Fig. 2, $A$ and $C$ ), which is consistent with the higher density of glycinergic AII-amacrine cells in the upper retina of the rat (Wässle et al., 1993).

\section{Subcellular localization of receptor subunits}

The punctate appearance of GlyR immunoreactivity suggests synaptic localization. This has been demonstrated in the retina by electron microscopy for gephyrin but not yet for the $\alpha 1$ subunit. The antigenic epitopes of the GlyR are highly sensitive to prolonged aldehyde fixation (Kirsch and Betz, 1993) and therefore relatively short fixation times were used in the present study. A fixation time of $30 \mathrm{~min}$ was found to be a good compromise between acceptable ultrastructural preservation and intense immunolabeling. In addition, the use of a silver intensification procedure significantly enhanced the visibility of the immunoreactive structures.

Immunoreactivity for the $\alpha 1$ subunit was localized exclusively in the synaptic cleft (Fig. $3 A$ ), indicating that $\mathrm{mAb} 2 \mathrm{~b}$ recognizes an antigenic epitope that is localized on the extracellular side of the plasma membrane. This is consistent with previous observations in the spinal cord (Triller et al., 1985) and ventral cochlear nucleus (Wenthold et al., 1988) and with the biochemical evidence that the N-terminal domain of the GlyR $\alpha 1$ sub- unit, which contains the major antigenic determinants (Schröder et al., 1991), is located extracellularly (Langosch et al., 1990).

It is now well established for the retina (Smiley and Yazulla, 1990; Pourcho and Owczarzak, 1991 b; Yazulla and Studholme, 1991 a,b; Zucker and Ehinger, 1992, 1993; Grünert and Wässle, 1993) as well as for other parts of the CNS (Triller et al., 1985, 1987; Altschuler et al., 1986; Seitanidou et al., 1988; van den Pol and Gorcs, 1988; Wenthold et al., 1988; Chen and Hillman, 1993; Mitchell et al., 1993) that gephyrin-LI is localized at the cytoplasmic face of the postsynaptic membranes. The pattern of labeling that we observed in the rat retina is consistent with this view. As shown in Figure 3B, gephyrin-LI was restricted to the cytoplasmic face of the postsynaptic membrane; however, in some cases, there was some diffusion of the reaction end product from the synapse to adjacent cytoplasmic regions.

\section{Localization of $\alpha 1$ subunit-LI in the IPL}

Consistent with the light microscopic results, the vast majority of immunopositive synapses were located in strata 1 and 2 of the IPL $(88 \%, n=147)$. In the inner part of the IPL, only a few immunoreactive synapses were observed $(12 \%, n=20)$. The analysis of the synaptic microcircuitry involving GlyRs showed that the $\alpha 1$ subunit was localized exclusively at conventional synapses, indicating that the presynaptic profile was always an amacrine cell process. In the inner part of the IPL, the postsynaptic profiles were usually small processes that could not be identified. Therefore, the following analysis concentrates on the distribution of the $\alpha 1$ subunit in the outer part of the IPL.

In many cases, the labeled synapses were characterized by large sizes (Fig. 4A). This could explain the large labeled punctate structures seen with the light microscope. The presynaptic profile at labeled synapses was frequently an amacrine cell process with the morphology of an AII-lobular appendage (Figs. $4 B$, 5) (Kolb, 1979; Strettoi et al., 1992; Chun et al., 1993). The postsynaptic profiles were the axonal endings of cone bipolar cells (Fig. $4 B$ ) and the dendrites of ganglion cells (Fig. 5). Other 

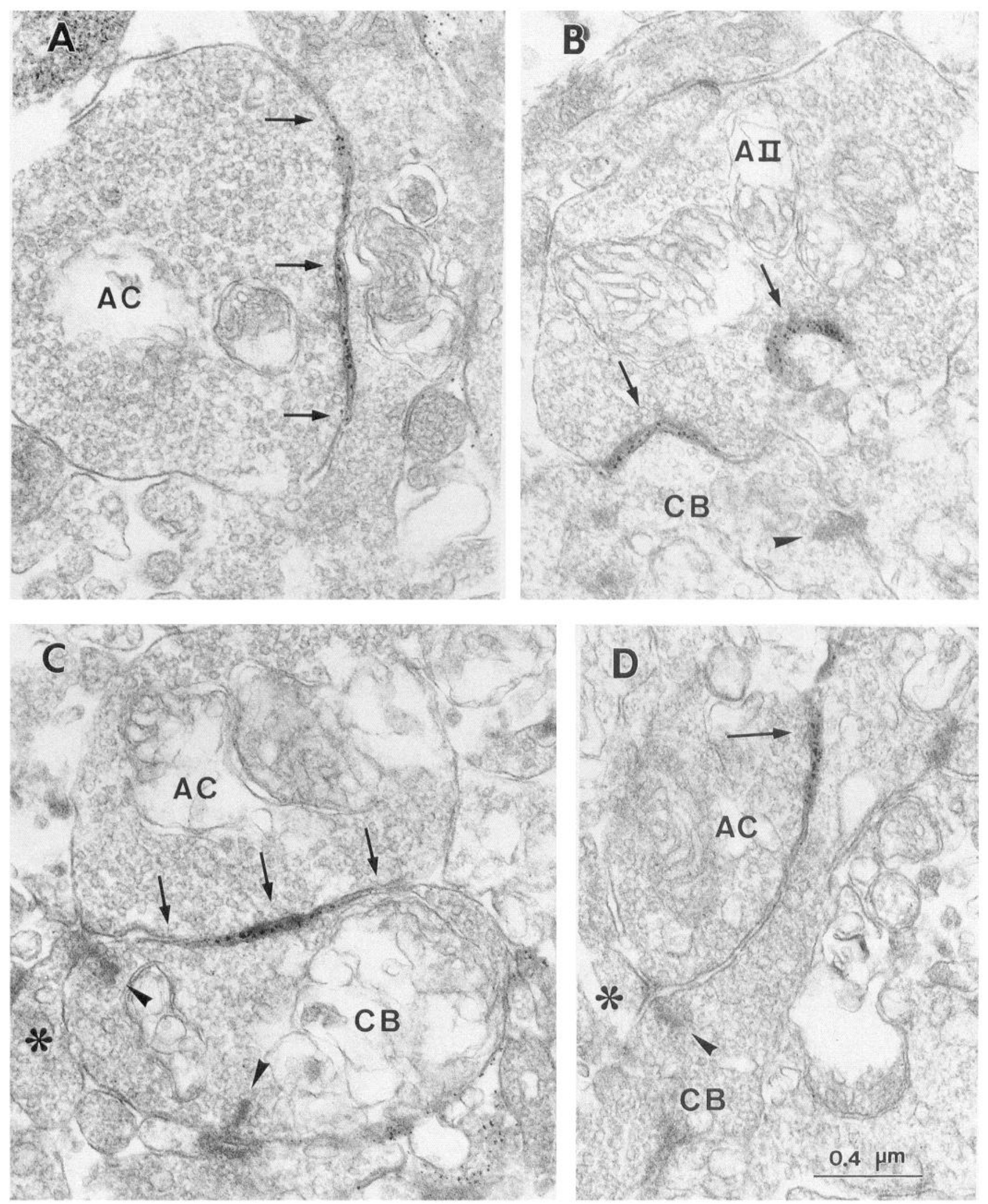

Figure 4. Electron micrographs showing immunoreactivity for the $\alpha 1$ subunit of the GlyR in the outer part of the IPL. A, A large amacrine process $(A C)$ makes a labeled synapse (arrows) with a process containing synaptic vesicles in stratum 1 . Note the large size of the synaptic contact. $B$, A large amacrine process with the morphology of an AII-lobular appendage $(A I I)$ makes labeled synapses (arrows) with a small unidentified profile and with a cone bipolar axon terminal $(C B)$. The arrowhead indicates the ribbon that identifies the bipolar terminal. $C$ and $D$, Two examples of $\alpha 1$-positive synapses from amacrine processes $(A C)$ to cone bipolar axons $(C B)$. Each amacrine cell process is both presynaptic to a bipolar terminal 


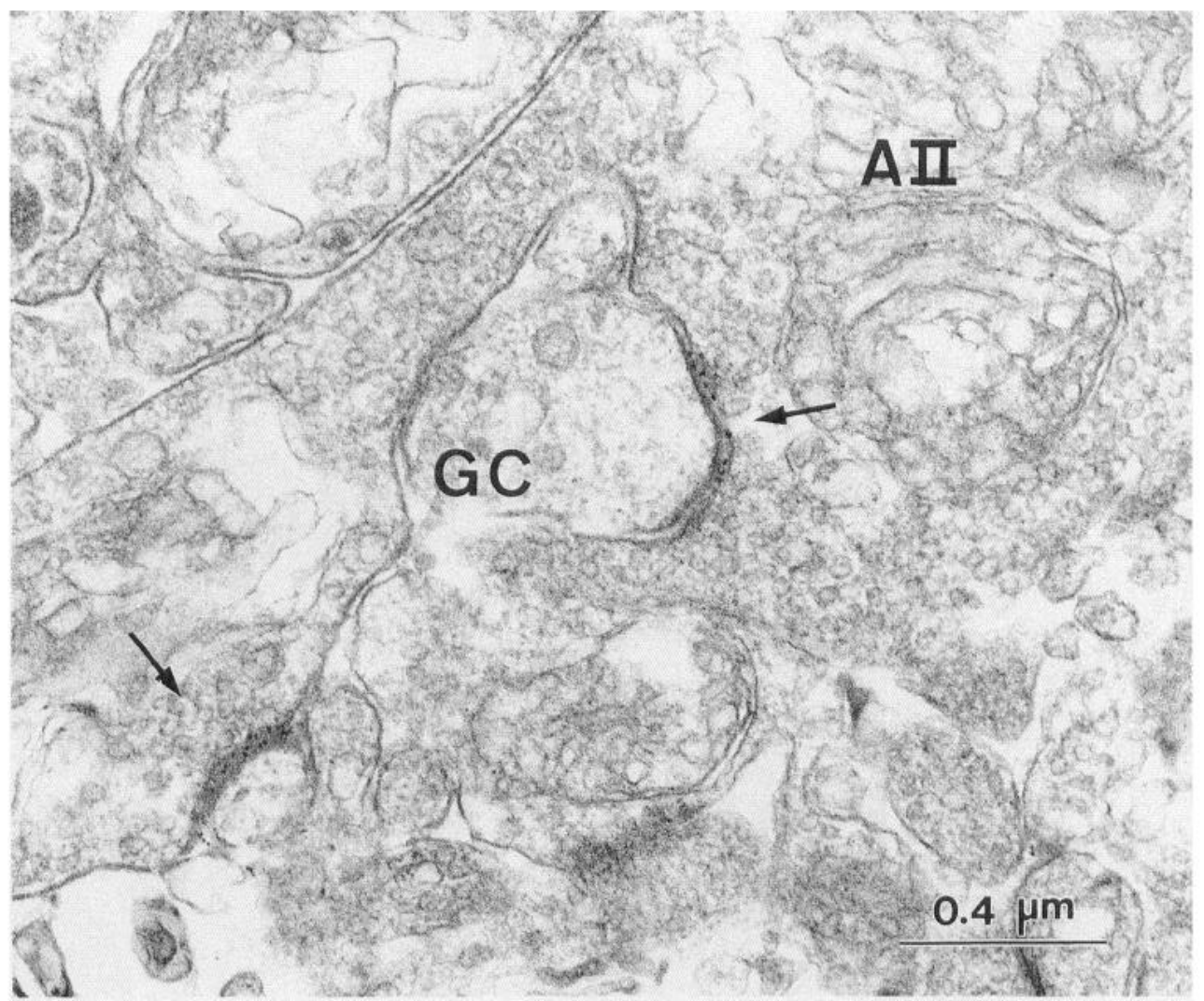

Figure 5. Electron micrograph showing two $\alpha 1$-positive synapses (arrows) in stratum 2. The presynaptic element $(A I I)$ is very likely the lobular appendage of an AII-amacrine cell. The two postsynaptic elements are a small unidentified profile and the dendrite of a ganglion cell $(G C)$. examples of $\alpha 1$-immunoreactive contacts involving an amacrine cell and a bipolar cell in the outer part of the IPL are shown in Figure $4, C$ and $D$. In these cases, an amacrine cell process is postsynaptic at a cone bipolar ribbon synapse and makes a reciprocal contact onto the bipolar cell terminal that is GlyR $\alpha 1$ positive. Reciprocal synapses between the processes of AIIamacrine cells and the axon terminals of cone bipolar cells have been described in the rat retina (Chun et al., 1993); therefore, the amacrine cell processes represented in Figure 4, $C$ and $D$, could also belong to AII-amacrines.

A more quantitative analysis showed that the majority $(65 \%$, $n=96$ ) of the postsynaptic profiles at labeled synapses in the outer part of the IPL were vesicle-containing processes. A total of 42 of these processes could be identified as bipolar cell axons because they contained a synaptic ribbon (Dowling and Boycott, 1966). The remaining 54 processes could also be of bipolar cells, but in these cases a synaptic ribbon was not seen in the series of consecutive sections that we analyzed. Thus, for these profiles it cannot be excluded that at least some of them are of amacrine cells. However, as will be shown by the colocalization studies presented below, it is more likely that the majority of these processes are also bipolar cell axons. About $16 \%(n=23)$ of the labeled synapses were on presumed ganglion cell dendrites (Fig. 5). Other labeled synapses involved small unidentified processes $(19 \%, n=28)$.

In one case, we observed an amacrine cell process making two synapses onto presumed ganglion cell dendrites. One syn- apse was GlyR $\alpha \mathrm{l}$ immunoreactive, while the other one was unlabeled (not shown). This finding indicates that the $\alpha 1$ subunit of the GlyR is not present at all the synapses made by presumed glycinergic amacrine cells and points to a heterogeneity of receptors apposed to glycinergic terminals, which could depend on the selective expression of different $\alpha$ subunits.

\section{Localization of gephyrin-LI in the IPL}

Consistent with the light microscopic observations, the density of gephyrin-immunopositive synaptic contacts was much higher than the number of synapses containing the $\alpha 1$ subunit of the GlyR. Gephyrin-immunopositive profiles were present throughout the IPL, but were more frequent in the outer strata. In agreement with findings in cat and monkey (Pourcho and Owczarzak, 1991b; Grünert and Wässle, 1993), the synapses immunoreactive for gephyrin always involved an amacrine cell process as the presynaptic element. The postsynaptic elements could be of either amacrine or ganglion cell origin. Synaptic staining was also seen in the inner part of the INL and in the GCL, where conventional synapses occurred with the cell bodies of amacrine and ganglion cells, respectively (not shown). This is consistent with the presence of gephyrin-immunopositive puncta in the INL and in the GCL shown in Figure $1 A$. Presumed AII-amacrine cells were seen to be presynaptic at labeled synapses in the outer part of the IPL (Fig. $6 \mathrm{~A}$ ) and gephyrin positive at sites of conventional amacrine cell input in the inner part of the IPL (Fig. 6B). Although in the present study relatively short

at a conventional synaptic contact, labeled with arrows, and postsynaptic to the same bipolar terminal at a ribbon (arrowheads) synapse. The other element of the dyad at the ribbon synapse is indicated by an asterisk. 

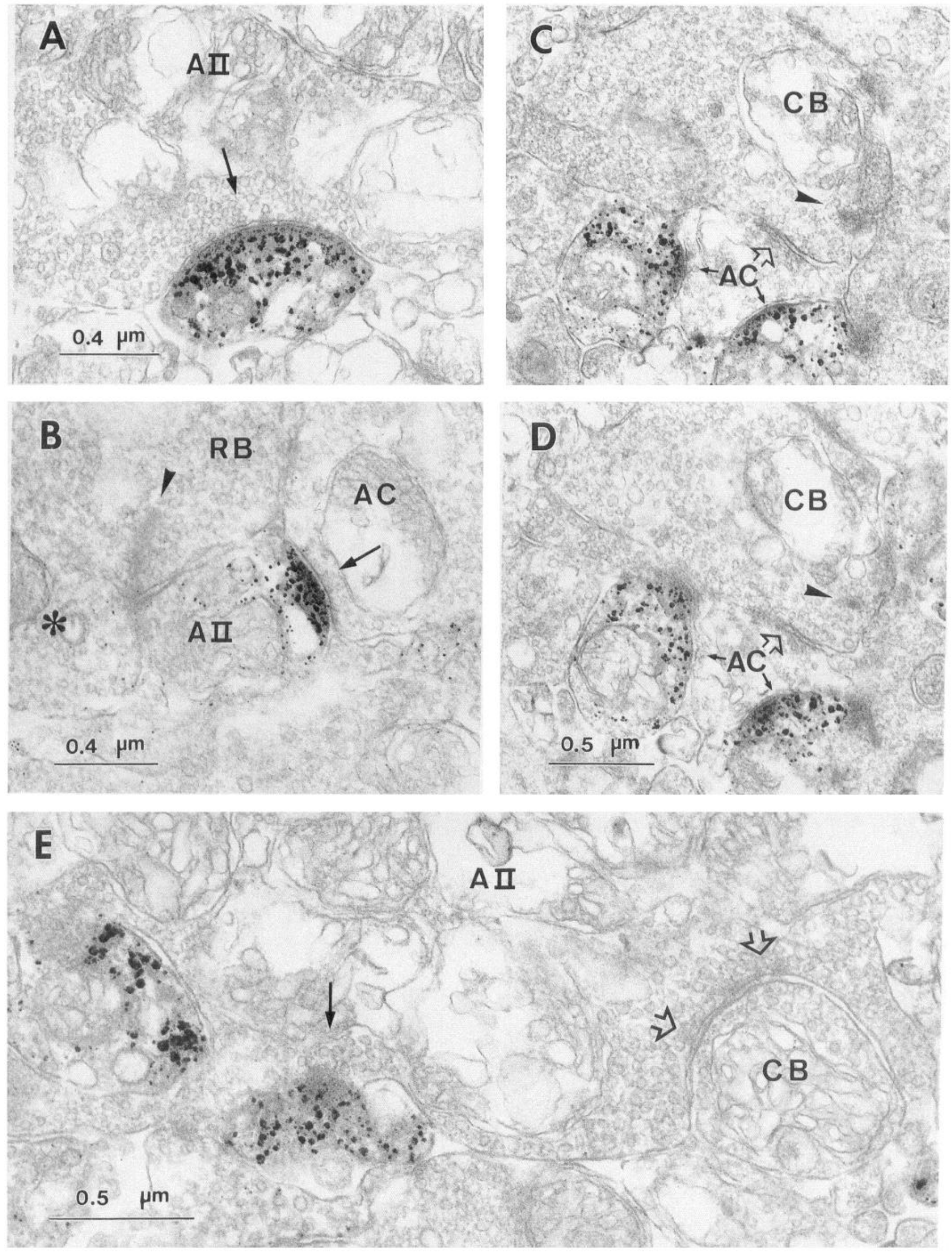
fixation times were used to increase the sensitivity of the immunocytochemical detection of GlyR polypeptides (Kirsch and Betz, 1993), gephyrin-positive bipolar axon terminals were never observed. In Figure 6, $C$ and $D$ show an amacrine cell process that is presynaptic to two gephyrin-positive profiles as well as to an unlabeled cone bipolar axon terminal. In the outer part of the IPL, we frequently observed processes with the morphology of AII-lobular appendages making gephyrin-positive contacts with presumed ganglion cell dendrites and gephyrinnegative contacts with cone bipolar cell axons (Fig. 6E).

\section{Localization of $\alpha I$ subunit-LI and gephyrin-LI in the OPL}

Very few immunoreactive synapses were observed in the OPL with both $\mathrm{mAbs} 2 \mathrm{~b}$ and $7 \mathrm{a}$ (Fig. $7 A, B$ ). These synapses were of the conventional type and therefore they probably represent the input from interplexiform cells to bipolar cells or to other interplexiform cells (Kolb and West, 1977; Linberg and Fischer, 1986). Frequently, the gephyrin-immunopositive contacts were found in regions of the OPL where also a cone pedicle was present. In two cases, a labeled process was seen to establish a contact with a cone pedicle, although no clear synaptic specializations were observed. Therefore, the gephyrin-positive processes that are present in the OPL could be the dendrites of cone bipolar cells. At present, it is not possible to establish whether the processes with gephyrin-LI are the same that are labeled by $\mathrm{mAb} 2 \mathrm{~b}$.

\section{Colocalization of the $\alpha$ I subunit with recoverin- immunoreactive bipolar cells}

The electron microscopic results show that the $\alpha$ l subunit of the GlyR is localized at synapses. We therefore conclude that the puncta detected by immunofluorescence (Figs. 1, 2) represent synaptic sites. In order to find out which bipolar cells are involved at these synapses and to what extent AII-amacrine cells are the presynaptic members, we performed double-immunofluorescence experiments. Specific staining of cone bipolar cells using antibodies against recoverin, a calcium-binding protein, has recently been reported by Milam et al. (1993).

The results of the double immunolabeling with $\mathrm{mAb} 2 \mathrm{~b}$ and with an antiserum against recoverin are shown in Figure $8, A$ and $B$. Recoverin immunofluorescence is very strong in photoreceptors (Fig. $8 \mathrm{~A}$ ), where this protein was originally described (Dizhoor et al., 1991; Lambrecht and Koch, 1991, 1992). In agreement with Milam et al. (1993), two populations of cone bipolar cells with axon terminals in the outer part of the IPL (the OFF-sublamina) and in the inner part of the IPL (the ONsublamina) are labeled. The axon terminals in the OFF-sublamina are diffuse: they fill strata 1 and 2 and exhibit many small varicosities. Those in the $\mathrm{ON}$-sublamina are restricted to a narrow band in stratum 4 and have large varicosities (Fig. $8 A$ ). GlyR $\alpha 1$-LI of the same section (Fig. $8 B$ ) has a punctate appearance, with more and larger puncta in the OFF-sublamina.
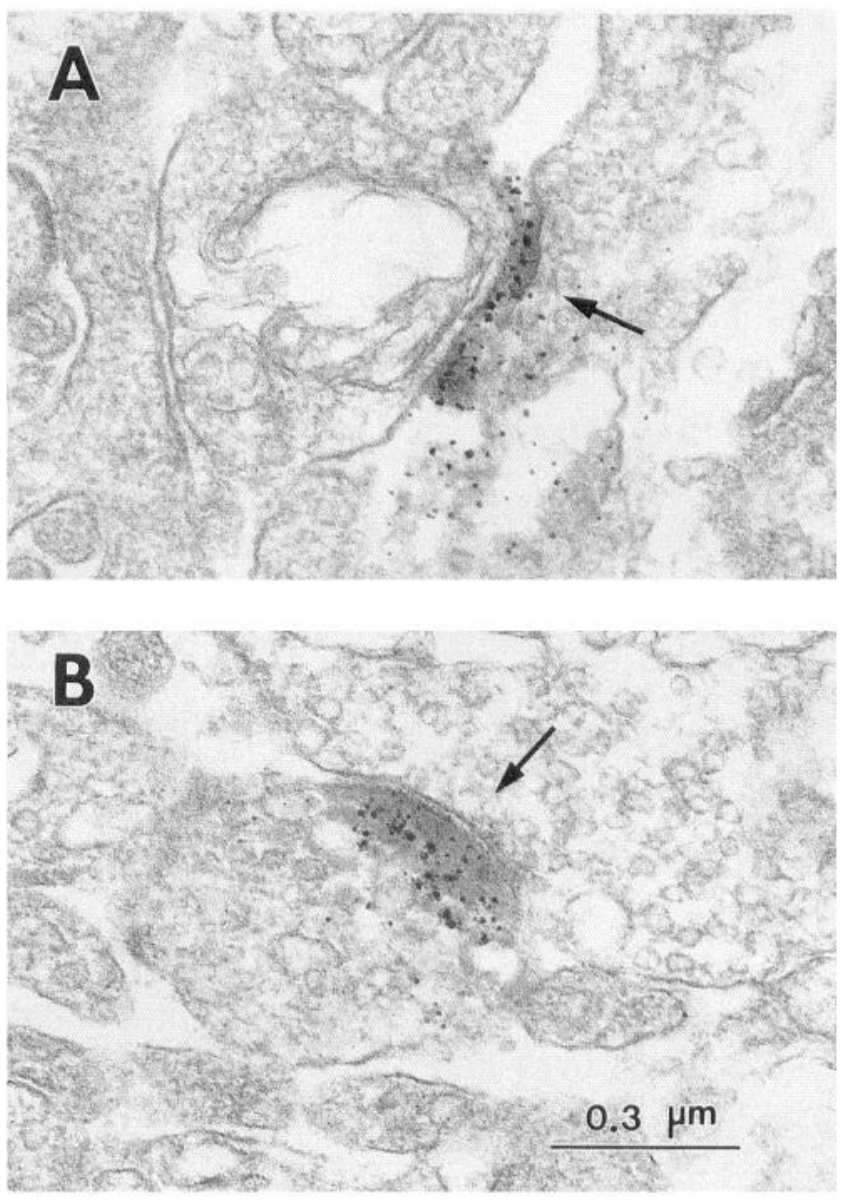

Figure 7. Electron micrographs of GlyR $\alpha 1$-positive (in $A$ ) and gephyrin-positive (in $B$ ) conventional synaptic contacts (arrows) in the outer plexiform layer. In both cases, the presynaptic element is presumably the process of an interplexiform cell, while the postsynaptic element could be the dendrite of a bipolar cell.

These puncta form clusters of irregular shapes. Comparison with the recoverin-labeled axon terminals (Fig. $8 \mathrm{~A}$ ) shows close correspondence between the arrangement of the puncta and the varicosities of the axon terminals. To show this in more detail, magnified drawings of Figure $8, A$ and $B$, are shown in Figure 9, $A$ and $B$, and the two patterns are superimposed in Figure $9 C$. Most of the puncta in the OFF-sublamina are in register with the axon terminals of recoverin-immunoreactive bipolar cells. In the ON-sublamina no such close correspondence can be detected. As described in the Materials and Methods, two sections were evaluated by three observers with respect to colocalization of GlyR $\alpha 1$ subunit and recoverin immunoreactivities. Of 502 puncta in the outer part of the IPL, $75 \pm 7 \%$ (mean $\pm \mathrm{SD}$ of the three observers) were found to be colocalized with

Figure 6. Electron micrographs of sections immunostained with the antibody against gephyrin. $A$, In the outer part of the IPL, an amacrine cell process with the morphology of an AII-lobular appendage $(A I I)$ makes a gephyrin-positive synapse (arrow) with a small profile that is presumably a ganglion cell dendrite. $B$, In stratum 5 of the IPL, the process of an AII-amacrine cell $(A I I)$ is gephyrin positive at a conventional synaptic input (arrow) from another amacrine process $(A C)$. The AlI-process also receives a ribbon synapse (arrowhead) from the axon terminal of a rod bipolar cell $(R B)$. The other amacrine process of the dyad is indicated by an asterisk. $C$ and $D$. Two consecutive sections showing an amacrine process $(A C)$ making three synaptic contacts. Two of these synapses (small arrows) are with gephyrin-positive postsynaptic elements. The remaining synapse (open arrow) is unlabeled and is with a cone bipolar axon terminal $(C B)$, identified by a ribbon (arrowhead). E. A presumed AII-lobular appendage $(A I I)$ makes a gephyrin-positive synapse (solid arrow) with a small, unidentified profile, as well as an unlabeled synapse (open arrows) with a bipolar cell terminal $(C B)$. The ribbon in the bipolar cell terminal was observed in a consecutive section. 

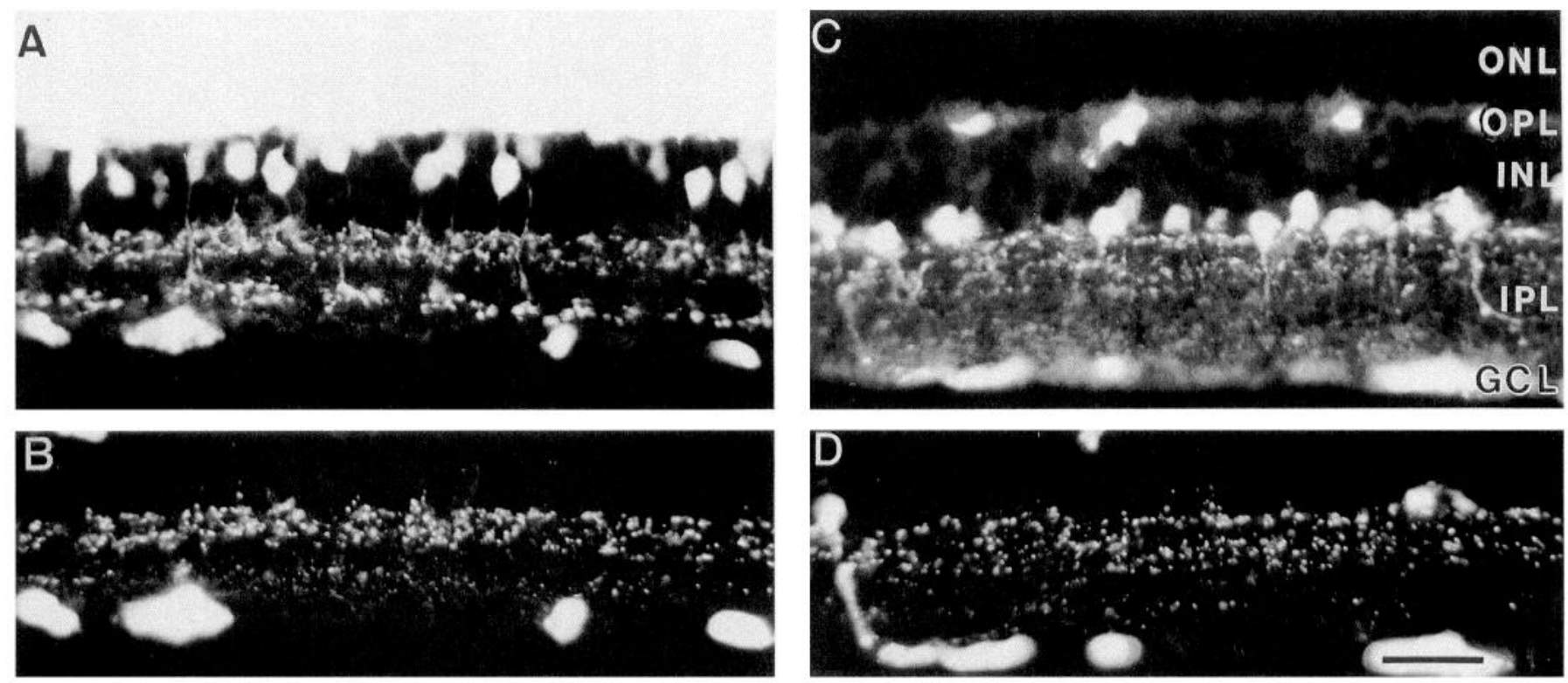

Figure 8. Fluorescence micrographs of vertical sections through rat retinas that were double immunostained. Abbreviations are as in Figure 1. $A$ and $B$ show the same section immunolabeled for recoverin (FITC fluorescence in $A$ ) and for the $\alpha 1$ subunit of the GlyR (CY3 fluorescence in $B$ ). $A$. The photoreceptors are strongly immunoreactive in the ONL, bipolar cell bodies are labeled in the INL, and their axon terminals form two bands in the IPL. B. Immunoreactivity for the $\alpha 1$ subunit has a punctate appearance, which is more prominent in the outer part of the IPL. Blood vessels of the GCL show unspecific fluorescence. $C$ and $D$ show the same section immunolabeled for parvalbumin (FITC fluorescence in $C$ ) and for the $\alpha 1$ subunit of the GlyR (CY3 fluorescence in $D$ ). $C$. Amacrine cell bodies and their processes descending into the IPL are labeled. $D$, Immunoreactivity for the $\alpha 1$ subunit has a punctate appearance and shows a higher density in the outer part of the IPL. Drawings of these micrographs are presented in Figures 9 and 10. Scale bar, $25 \mu \mathrm{m}$.

recoverin-positive axon terminals. Of 215 puncta in the inner part of the IPL, $38 \pm 6.5 \%$ were associated with recoverinpositive bipolar cell axon terminals. These results lead to the conclusion that in the outer part of the IPL the majority of the $\alpha 1$-positive puncta are present at synapses in which the postsynaptic element is the axon of a putative OFF-cone bipolar cell.

\section{Colocalization of the $\alpha 1$ subunit with AII-amacrine cell processes}

In order to identify which amacrine cell might be involved in these contacts, we performed a double-labeling experiment with $\mathrm{mAb} 2 \mathrm{~b}$ and an antiserum against PV. The antiserum against PV has recently been shown to be a valuable probe for the identification of the glycinergic AII-amacrine cell in the rat retina (Wässle et al., 1993). The results are shown in Figure 8, C and $D$. PV immunofluorescence is found in amacrine cell bodies at the INL/IPL border and in processes running diffusely through the IPL (Fig. $8 C$ ). In the outer part of the IPL, small varicose processes can be detected, which are typical for AII-amacrine cells. In the same section, the antibody against the $\alpha 1$ subunit of the GlyR reveals the typical punctate staining pattern (Fig. $8 D$ ). Magnified drawings of the two micrographs are shown in Figure $10, A$ and $B$, and are superimposed in Figure $10 C$. Comparison of the micrographs (Fig. $8 C, D$ ) and of the drawing in Figure $10 C$ shows that in the outer part of the IPL many $\alpha 1$ positive puncta are in register with PV-labeled profiles. Frequently, these profiles exhibit the typical morphology of AIIcell lobular appendages. A quantitative analysis of two sections by the three observers showed that of $635 \alpha 1$-positive puncta in the outer part of the IPL, $71 \pm 6 \%$ were colocalized with PVlabeled profiles. In the inner part of the IPL we found less colocalization ( $32 \pm 7 \%$ out of a total of $259 \alpha 1$-positive puncta).
Since the large majority of PV-positive amacrine cells are AII-amacrines (Wässle et al., 1993), these observations strongly indicate that the $\alpha 1$ subunit of the GlyR is present at the chemical synapses established by AII-lobular appendages in the outer part of the IPL.

The colocalization of $\alpha 1$ subunit-LI with PV-LI observed in the inner part of the IPL, where the AII-amacrine receives inputs from other amacrine cells (Strettoi et al., 1992), suggests that AII-amacrines themselves may express the $\alpha 1$ subunit of the GlyR. This is further supported by the recent finding of glycineactivated and strychnine-sensitive chloride channels on AIIamacrines of the rat retina (Boos et al., 1993). Finally, the finding that approximately $30 \%$ of the $\alpha 1$-positive "puncta" in the outer IPL were not associated with PV-immunoreactive profiles is consistent with the presence of other types of glycinergic amacrine cells (Marc, 1989; Vaney, 1990). However, the major conclusion of the double-labeling studies in conjunction with the electron microscopic results is that the majority of synapses in the outer part of the IPL that contain the $\alpha 1$ subunit of the GlyR are synapses between AII-amacrine cells and OFF-cone bipolar axons.

\section{Discussion}

\section{Subunit composition of the GlyR}

The $93 \mathrm{kDa}$ protein gephyrin is not a membrane-spanning subunit of the GlyR, but is located on the cytoplasmic side of the postsynaptic membrane at presumed glycinergic synapses (Langosch et al., 1990). Many authors have described the localization of GlyRs using the antibody directed against gephyrin (Triller et al., 1985, 1987; Altschuler et al., 1986; Jäger and Wässle, 1987; Araki et al., 1988; Basbaum, 1988; Seitanidou et al., 1988; van den Pol and Gorcs, 1988; Wenthold et al., 1988; Smiley and Yazulla, 1990; Pourcho and Owczarzak, 1991b; Yazulla 

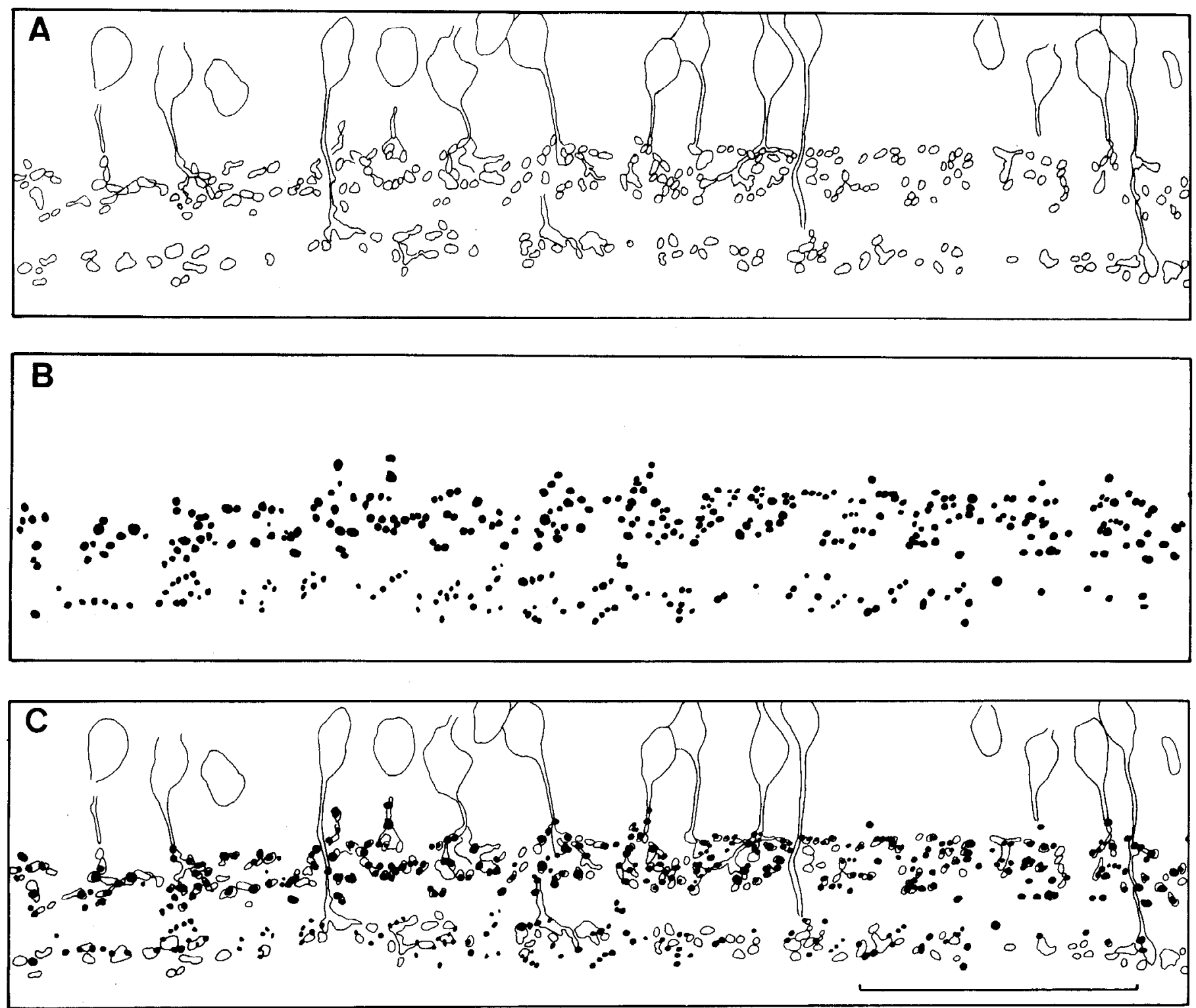

Figure 9. Drawings of the section double labeled for recoverin-LI and $\alpha 1$-LI shown in Figure $8, A$ and $B$. $A$, Drawing of the recoverin-immunoreactive bipolar cells from the micrograph in Figure $8 A$. Two populations are labeled. The axon terminals of putative OFF-cone bipolar cells form a broad band in the outer part of the IPL, those of the putative ON-cone bipolar cells terminate in a more narrow band in the inner part of the IPL. $B$, Drawing of the $\alpha 1$-immunoreactive puncta from the micrograph in Figure $8 B$. They are also arrayed in two bands, a broader, outer band with many large puncta and a narrow inner band with smaller puncta. $C$, The superposition of $A$ and $B$ shows that most of the puncta of the outer band are in register with axon terminals of putative OFF-cone bipolar cells. Scale bar, $50 \mu \mathrm{m}$.

and Studholme, $1991 \mathrm{a}, \mathrm{b} ;$ Zucker and Ehinger, 1992, 1993; Chen and Hillman, 1993; Mitchell et al., 1993). Pourcho and Owczarzak (1991b) have shown that in the cat retina gephyrin-LI is present in profiles that are postsynaptic to glycine-immunoreactive amacrine cells. Recently it has been demonstrated that in many brain regions gephyrin is expressed independently of the GlyR $\alpha$ (ligand-binding) subunits (Kirsch and Betz, 1993). The immunocytochemical data presented in this study are consistent with this view and show that in the retina gephyrin is also much more widely distributed than the $\alpha$ l subunit of the GlyR. Indeed, synapses that were immunopositive for gephyrin were found throughout the IPL, whereas immunoreaclivily for the $\alpha 1$ subunit was mainly confined to the outer part. Therefore, gephyrin localization in the rat retina cannot be limited to GlyRs expressing the $\alpha$ l subunit.
There are three possible explanations for the differences in distribution of gephyrin and the $\alpha 1$ subunit. (1) Gephyrin is present at glycinergic synapses that express GlyR subunits other than the $\alpha 1$. (2) Gephyrin is expressed not only at glycinergic synapses, but also at other types, such as GABAergic synapses. (3) There are GlyRs that do not contain gephyrin, or that contain an alternative form of gephyrin that is not recognized by $\mathrm{mAb}$ 7a. There is evidence for all three possibilities.

In support of the first explanation, it has recently been shown in our laboratory that mRNAs encoding for all GlyR $\alpha$ subunits $(\alpha 1, \alpha 2, \alpha 3)$ are expressed in the rat retina (Greferath et al., 1994). Since each of these subunits shows a specific expression pattern, it is possible that different types of GlyRs (containing different $\alpha$ isoforms) are present in the retina. This is further supported by the finding that $\mathrm{mAb} 4 \mathrm{a}$, which recognizes all $\alpha$ 

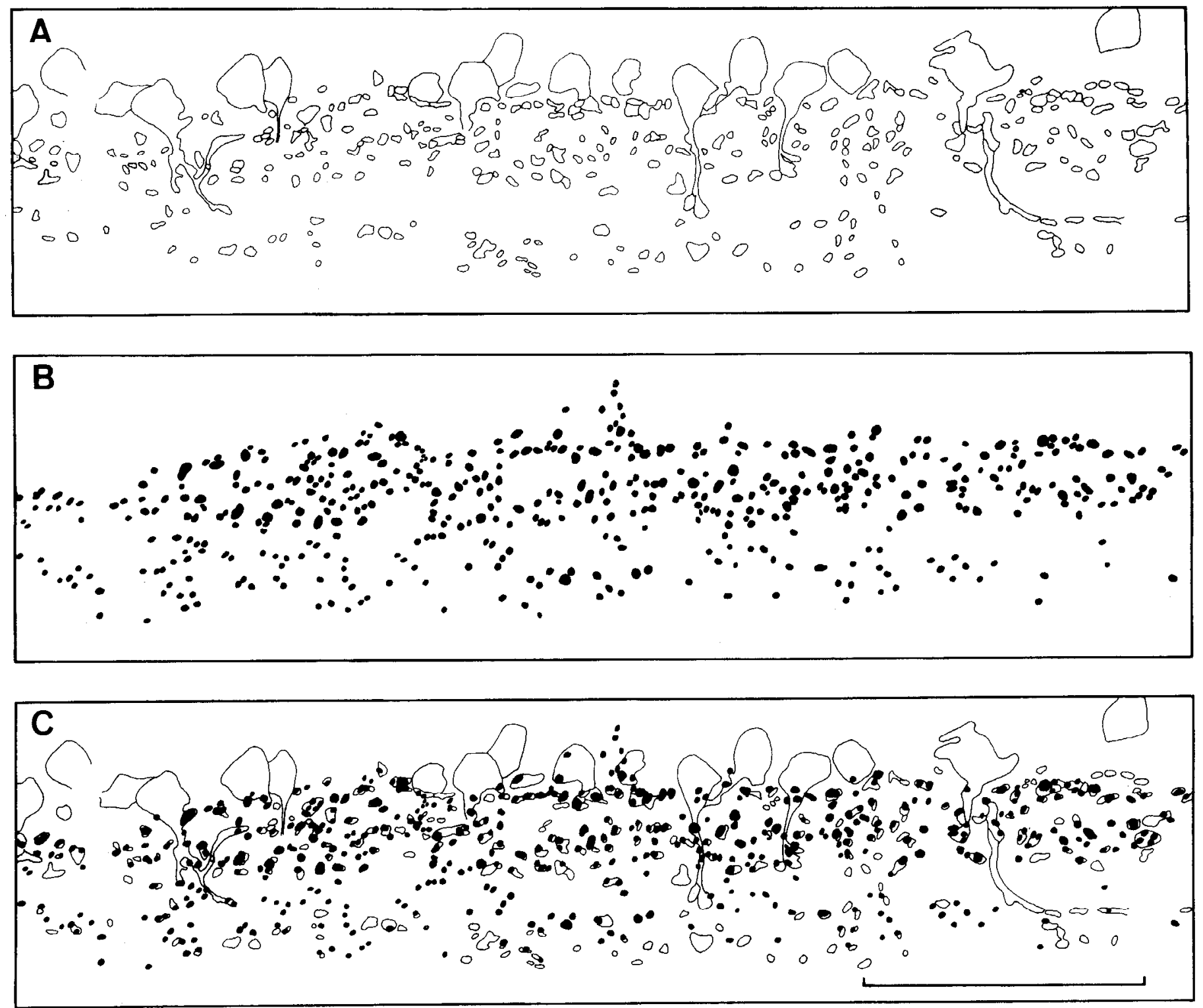

Figure 10. Drawings of the section double labeled for PV-LI and $\alpha 1$-LI shown in Figure 8, $C$ and $D$. $A$, Drawing of the parvalbumin-immunoreactive amacrine cells from the micrograph in Figure $8 C$. Some of the labeled cell bodies have the typical appearance of AII-amacrine cells, with a single descending process and lobular appendages. $B$, Drawing of the $\alpha 1$-immunoreactive puncta from the micrograph in Figure $8 D$. $C$, Superposition of $A$ and $B$ shows the extensive colocalization of the puncta with PV-immunoreactive processes in the outer band of the IPL, where AII-amacrine cells have their lobular appendages. Scale bar, $50 \mu \mathrm{m}$.

subunits and the $\beta$ subunit of the GlyR, stains many more puncta than the antibody (mAb 2b) specific for the $\alpha$ l subunit (Grünert and Wässle, 1993). In conclusion, these results indicate that the retina might contain GlyRs which do not have the $\alpha 1$ subunit and gephyrin might be present at these receptors.

In support of the second explanation, it has been shown in the spinal cord and in the cerebellum that putative GABAergic terminals are apposed to gephyrin-immunoreactive postsynaptic specializations (Triller et al., 1987; Cabot et al., 1993; Chen and Hillman, 1993; Mitchell et al., 1993). Indirect evidence for the presence of gephyrin at GABAergic synapses is also available in the retina (Yazulla and Studholme, 1991b). However, the situation might be even more complicated: in situ hybridization studies in the rat brain have shown that the spatial and temporal distribution of gephyrin transcripts is different from that of the known $\alpha$ (ligand-binding) subunits of the GlyR, but is similar to that of the GlyR $\beta$ subunit mRNA (Malosio et al., 1991a; Kirsch et al., 1993a). This finding has led to the suggestion that both gephyrin and the $\beta$ subunit of the GlyR could be components of novel types of inhibitory ligand-gated ion channels, and assembly of the GlyR $\beta$ polypeptide with $\mathrm{GABA}_{\mathrm{A}}$ receptor subunits has been envisaged (Malosio et al., 1991a). Consistent with this idea is the finding that GlyR $\beta$ subunit and $\mathrm{GABA}_{\mathrm{A}}$ receptor $\gamma$ subunit mRNAs are expressed by the same neurons in the rat dorsal root ganglion cells (Furuyama et al., 1992) and these subunits might therefore be coassembled in a functional receptor. However, at present, there is no direct evidence that gephyrin is associated with any type of GABA receptor.

One major finding of the present study is that the axons of some cone bipolar cells express the $\alpha 1$ subunit of the GlyR but not gephyrin. Hence, we also support the third explanation men- 
tioned above, that there are glycinergic synapses and receptors that do not contain gephyrin, at least in the form recognized by $\mathrm{mAb} 7 \mathrm{a}$. Two previous investigations of the mammalian retina were also unable to detect gephyrin-LI in bipolar cell axons and suggested the existence of an alternative form of the GlyR that does not contain the $93 \mathrm{kDa}$ component (Pourcho and Owczarzak, 1991b; Grünert and Wässle, 1993). Indeed, our results provide strong evidence for the existence of GlyRs in which gephyrin is not expressed. This situation seems to differ from that reported for the goldfish retina, where some gephyrin-immunoreactive synapses were found on the axon terminals of mixed rod-cone bipolar cells (Yazulla and Studholme, 1991b).

Recently, Mitchell et al. (1993) have described the distribution of gephyrin-LI in the dorsal horn of rat spinal cord. They found that the same presynaptic axonal endings could form gephyrin-immunopositive axodendritic synapses and gephyrinimmunonegative axoaxonic synapses. Since glycine and GABA may coexist at many of these synapses, the authors suggested that either only GABA acts at axoaxonic synapses or that glycine acts at a receptor that does not contain gephyrin. This situation is reminiscent of the one we have observed in the retina. Here, the lobular appendages of AII-amacrine cells make gephyrinimmunopositive synapses with the dendrites of ganglion cells and gephyrin-immunonegative synapses with the axonal endings of cone bipolar cells. There is evidence that glycine is used as a neurotransmitter at all these synapses: first, glycine is the only neuroactive substance that has been found in AII-amacrine cells; second, the synapses established by AII-amacrine cells with the axons of OFF-cone bipolar cells can be blocked by strychnine (Müller et al., 1988); third, the $\alpha 1$ subunit of the GlyR is present at these synapses (present results). Therefore, our data, taken together with those of Mitchell et al. (1993), indicate that there could be an interesting molecular specification: gephyrin could be a component of GlyRs in dendrites, but not in axons (but see Yazulla and Studholme, 1991b). Since the presence of gephyrin is important for the clustering of GlyRs at postsynaptic sites (Kirsch et al., 1993b), the mechanisms that underlie this function in the axonal compartment could differ from those in the somatodendritic compartment.

\section{Localization of the GlyR $\alpha 1$ subunit in the retina}

The synaptic contacts exhibiting immunoreactivity for the $\alpha 1$ subunit were identified as synapses established by amacrine cells onto other processes. This observation is consistent with physiological and pharmacological evidence that many amacrines are involved in glycinergic inhibitory neurotransmission (Wässle et al., 1986, 1991; Müller et al., 1988; Daw et al., 1989; Wässle and Boycott, 1991). Studies of glycine uptake and immunoreactivity have revealed different populations of glycinecontaining amacrine cells (Ehinger and Falck, 1971; Pourcho, 1980; Frederick et al., 1984; Marc and Liu, 1985; Pourcho and Goebel, 1985a,b, 1987a,b; Cohen and Sterling, 1986; Wässle et al., 1986; Hendrickson et al., 1988; see also reviews: Marc, 1989; Vaney, 1990). In the cat, four types (A3, A4, A7 or AII, A8) have been described, each possessing small dendritic fields (Pourcho, 1980; Pourcho and Goebel, 1985a). In the rat retina, very little is known about the morphology of glycinergic amacrine cells, with the exception of the AII-amacrine cell (Chun et al., 1993; Wässle et al., 1993). The double-immunolabeling experiment using the antiserum against $\mathrm{PV}$ in combination with $\mathrm{mAb} 2 \mathrm{~b}$ revealed that the synapses established by AII-lobular appendages can account for the majority of $\alpha 1$-positive contacts observed in the outer part of the IPL. There were, however, other GlyR $\alpha 1$-immunoreactive elements that were not associated with PV-positive processes. This indicates that the rat retina contains additional populations of glycinergic amacrine cells, which could correspond to the types A3 and A4 described in the cat. Among all of the glycine-accumulating amacrine cells, cat-type A8 is the only cell with a significant number of synapses in the inner part of the IPL (Marc, 1989). If this cell type has a counterpart in the rat retina, it could be responsible for the labeling observed in the inner part of the IPL.

Three different cell types were found to cxpress the $\alpha 1$ subunit of the GlyR: bipolar cells, ganglion cells, and amacrine cells. The double-immunolabeling experiment using the antiserum against recoverin in combination with $\mathrm{mAb} 2 \mathrm{~b}$ indicated that in the outer part of the IPL the majority of the synapses involving the $\alpha 1$ subunit is on the axons of recoverin-positive bipolar cells. The additional finding that in the outer part of the IPL the majority of the $\alpha 1$-positive synapses are colocalized with PV-LI necessarily leads to the conclusion that the recoverin-positive bipolar cells receive glycinergic inputs from AIIamacrines. However, we cannot exclude that other types of glycinergic amacrine cells are also presynaptic to cone bipolars at synapses containing the $\alpha 1$ subunit.

\section{GlyRs in retinal circuitry}

The $\alpha 1$ polypeptide is a ligand-binding subunit of the strychnine-sensitive, adult-type GlyR (Grenningloh et al., 1987; Becker et al., 1988; Hoch et al., 1989). Variants of this subunit have been identified (Grenningloh et al., 1990; Kuhse et al., 1990a,b) and mRNAs encoding for all these isoforms are expressed in the rat retina (Greferath et al., 1994). Therefore, it is possible that not all GlyR polypeptides were revealed by our immunocytochemical investigation. The question then arises whether the observed distribution of the GlyR $\alpha 1$ subunit is sufficient to account for the known physiological effects of glycine in the retina.

Bolz et al. (1985) have reported that the light-evoked responses of all ON-center and OFF-center brisk ganglion cells of the cat retina can be blocked by glycine. This is consistent with the presence of $\alpha 1$-immunoreactive synapses in two major bands (Grünert and Wässle, 1993; present results) that correspond to the ON- and OFF-sublaminae (Famiglietti and Kolb, 1976; for rat: Famiglietti and Vaugh, 1981; Peichl, 1989).

Müller et al. (1988) found that strychnine could block the light modulation of OFF-ganglion cells in dark-adapted animals (see also Wässle et al., 1991). This is consistent with the presence of the $\alpha 1$ subunit at the glycinergic chemical synapses made by AII-amacrines onto OFF-bipolar and OFF-ganglion cells, since expression of the $\alpha 1$ subunit results in GlyRs of strong strychnine sensitivity (Schmieden et al., 1989). Therefore, we conclude that the $\alpha 1$ subunit of the GlyR is involved in the modulation of the OFF-cone pathway by the rod pathway.

Rod bipolar cells have been reported to possess glycine-gated chloride channels (Karschin and Wässle, 1990; Suzuki et al., 1990). However, our results do not support the presence of the $\alpha 1$ subunit in the axon terminals of these cells. In fact, only weak labeling was observed in the innermost part of the IPL, where the synaptic terminals of rod bipolars are located (Negishi et al., 1988; Greferath et al., 1990; Chun et al., 1993). Our results raise the possibility that rod bipolar cells express an alternative form of the GlyR which does not contain the $\alpha 1$ subunit.

A point to consider is whether cone bipolar cells can use 
glycine as a neurotransmitter. In the cat and primate retina, these cells have been found to accumulate or contain glycine (Frederick et al., 1984; Marc and Liu, 1985; Cohen and Sterling, 1986; Wässle et al., 1986; Pourcho and Goebel, 1987a; Hendrickson et al., 1988; Davanger et al., 1991; Martin and Grünert, 1992), but the functional significance of this observation has not yet been elucidated (reviewed in Marc, 1989). It has been suggested that glycine diffuses into cone bipolars through the gap junctions that these cells establish with the All-amacrines (Marc and Liu, 1985; Cohen and Sterling, 1986). Our results clcarly demonstrate that the GlyR $\alpha \mathrm{l}$ subunit is not present at sites postsynaptic to cone bipolar axon terminals and hence do not support a role of glycine as a neurotransmitter in these neurons. However, it is still possible that a different form of GlyR is present. Alternatively, glycine released from cone bipolar cells could potentiate the excitatory response at NMDA receptors. In agreement with this hypothesis, it has been recently shown in our laboratory that one subunit of the NMDA receptor (NR2A) is localized at sites postsynaptic to cone bipolar cells in the rat retina (Hartveit et al., 1994).

\section{Conclusions}

Molecular studies have shown that heterogeneity of the GlyR originates from the existence of different $\alpha$-subunit genes encoding isoforms of distinct pharmacology as well as from alternative splicing of their primary transcripts (Grenningloh et al., 1987, 1990; Schmieden et al., 1989; Sontheimer et al., 1989; Kuhse et al., 1990a,b, 1991; Malosio et al., 1991b). The immunocytochemical data presented in this study reveal that additional diversity could arise from the existence of two immunologically distinct types of GlyRs, one of which lacks the $93 \mathrm{kDa}$ protein gephyrin. Previous investigations have also reported the lack of gephyrin-LI at presumed glycinergic synapses (Zucker and Ehinger, 1992; Chen and Hillman, 1993; Mitchell et al., 1993). In these cases, colocalization of multiple neuroactive substances (e.g., glycine and GABA) was invoked as a possible explanation for the heterogeneity of receptors, which means that only a portion of the postsynaptic sites contacted by glycineutilizing neurons could respond to glycine. Alternatively, it has been suggested that glycine could act at a different type of receptor that does not possess gephyrin. Here we provide evidence that, in the rat retina, the latter explanation is indeed valid. Our results indicate that the use of $\mathrm{mAb} 7 \mathrm{a}$, specific for gephyrin, as a marker for GlyRs must be approached with caution. In fact, gephyrin seems to be more broadly distributed than GlyRs and a form of GlyR that lacks gephyrin is expressed by cone bipolar cells of the rat retina.

\section{References}

Altschuler RA, Betz H, Parakkal MH, Reeks KA, Wenthold RJ (1986) Identification of glycinergic synapses in the cochlear nucleus through immunocytochemical localization of the postsynaptic receptor. Brain Res 369:316-320.

Araki T, Yamano M. Murakami T, Wanaka A, Betz H, Tohyama M (1988) Localization of glycine receptors in the rat central nervous system: an immunocytochemical analysis using monoclonal antibody. Neuroscience 25:613-624.

Basbaum A (1988) Distribution of glycine receptor immunoreactivity in the spinal cord of the rat: cytochemical evidence for a differential glycinergic control of lamina I and V nociceptive neurons. J Comp Neurol 278:330-336.
Becker C-M, Hoch W, Betz H (1988) Glycine receptor heterogeneity in rat spinal cord during postnatal development. EMBO J 7:37173726.

Betz H (1991) Glycine receptors: heterogenous and widespread in the mammalian brain. Trends Neurosci 14:458-451.

Betz H (1992) Structure and function of inhibitory glycine receptors. Q Rev Biophys 25:381-394.

Betz H, Kuhse J, Schmieden V, Malosio M-L, Langosch D, Prior P, Schmitt B, Kirsch J (1991) How to build a glycinergic postsynaptic membrane. J Cell Sci [Suppl] 15:23-25.

Bolz J, Thier P, Voigt T, Wässle H (1985) Action and localization of glycine and taurine in the cat retina. J Physiol (Lond) 362:395-413.

Boos R, Schneider H, Wässle H (1993) Voltage- and transmitter-gated currents of AII-amacrine cells in a slice preparation of the rat retina. J Neurosci 13:2874-2888.

Bormann J, Rundström N, Betz II, Langosch D (1993) Residues within transmembrane segment $\mathrm{M} 2$ determine chloride conductance of glycine receptor homo- and hetero-oligomers. EMBO J 12:3729-3337.

Cabot JB, Bushnell A, Alessi V (1993) Electron microscopic localization of postsynaptic glycine receptor $(93 \mathrm{kD})$ in sympathetic preganglionic neurons: relationship to GABA- and non-GABA-containing synaptic terminals. Soc Neurosci Abstr 19:1484.

Chen S, Hillman DE (1993) Colocalization of neurotransmitters in the deep cerebellar nuclei. J Neurocytol 22:81-91.

Chun M-H, Han S-H, Chung J-W, Wässle H (1993) Electron microscopic analysis of the rod pathway of the rat retina. J Comp Neurol 332:421-432.

Cohen E, Sterling P (1986) Accumulation of $\left[{ }^{3} \mathrm{H}\right]$-glycine by cone bipolar neurons in the cat retina. J Comp Neurol 250:1-7.

Davanger S, Ottersen OP, Storm-Mathisen J (1991) Glutamate, GABA, and glycine in the human retina: an immunocytochemical investigation. J Comp Neurol 311:483-494.

Daw NW, Brunken WJ, Parkinson D (1989) The function of synaptic transmitters in the retina. Annu Rev Neurosci 12:205-225.

Dizhoor A, Ray S, Kumar S, Niemi G, Spencer M, Brolley D, Walsh K, Philipov P, Hurley J, Stryer L (1991) Recoverin: a calcium sensitive activator of retinal rod guanylate cyclase. Science 251:915-918.

Dowling JE, Boycott BB (1966) Organization of the primate retina: electron microscopy. Proc R Soc London [Biol] 166:80-111.

Ehinger B, Falck B (1971) Autoradiography of some suspected neurotransmitter substances: GABA, glycine, glutamic acid, histamine, dopamine, and L-dopa. Brain Res 33:157-172.

Famiglietti EV, Kolb H (1975) A bistratified amacrine cell and synaptic circuitry in the inner plexiform layer of the retina. Brain Res 84:293-300

Famiglietti EV, Kolb H (1976) Structural basis for ON- and OFFcenter responses in retinal ganglion cells. Science 194:193-165.

Famiglietti EV, Vaughn JE (1981) Golgi-impregnated amacrine cells and GABAergic retinal neurons: a comparison of dendritic, immunocytochemical and histochemical stratification in the inner plexiform layer of rat retina. J Comp Neurol 197:129-139.

Frederick JM, Rayborn ME, Hollyfield JE (1984) Glycinergic neurons in the human retina. J Comp Neurol 227:159-172.

Furuyama T, Sato M, Sato K, Araki T, Inagaki S, Takagi H, Tohyama $M$ (1992) Co-expression of glycine receptor $\beta$ subunit and GABA receptor $\gamma$ subunit mRNA in the rat dorsal root ganglion cells. Mol Brain Res 12:335-338.

Graham D, Pfeiffer F, Simler R, Betz H (1985) Purification and characterization of the glycine receptor of pig spinal cord. Biochemistry 24:990-994.

Greferath U, Grünert U, Wässle H (1990) Rod bipolar cells in the mammalian retina show protein kinase C-like immunoreactivity. $\mathrm{J}$ Comp Neurol 301:433-442.

Greferath U, Brandstätter JH, Wässle H, Kirsch J, Kuhise J, Grünert U (1994) Differential expression of glycine receptor subunits in the retina of the rat: a study using immunohistochemistry and in situ hybridization. Vis Neurosci, in press.

Grenningloh G, Rienitz A, Schmitt B, Hethfessel C, Zensen M, Beyreuther K, Gundelfinger E, Betz H (1987) The strychnine-binding subunit of the glycine receptor shows homology with nicotinic acetylcholine receptors. Nature 328:215-220.

Grenningloh G, Schmieden V, Schoficld PR, Seeburg PII, Siddique T, Mohandas TK, Becker C-M, Betz H (1990) Alpha subunit variants of the human glycine receptor: primary structures, functional expression and chromosomal localization of the corresponding gene. EMBO J 9:771-776. 
Grünert U, Wässle H (1993) Immunocytochemical localization of glycine receptors in the mammalian retina. J Comp Neurol 335:523537.

Harlow E, Lane D (1988) Antibodies, a laboratory manual. Cold Spring Harbor, NY: Cold Spring Harbor Laboratory.

Hartveit E, Brandstätter JH, Sassoè-Pognetto M, Laurie DJ, Seeburg PH, Wässle H (1994) Localization and developmental expression of the NMDA receptor subunit NR2A in the mammalian retina. $J$ Comp Neurol, in press.

Hendrickson AE, Koontz MA, Pourcho RG, Sarthy PV, Goebel DJ (1988) Localization of glycine-containing neurons in the Macaca monkey retina. J Comp Neurol 273:473-487.

Hoch W, Betz H, Becker C-M (1989) Primary cultures of mouse spinal cord express the neonatal isoform of the inhibitory glycine receptor. Neuron 3:339-348.

Hsu P, Raine L, Fanger H (1981) Use of avidin-biotin peroxidase complex $(A B C)$ in immunoperoxidase techniques. J Histochem Cytochem 29:577-580.

Jäger J, Wässle H (1987) Localization of glycine uptake and receptors in the cat retina. Neurosci Lett 75:147-151.

Karschin A, Wässle H (1990) Voltage- and transmitter-gated currents in isolated rod bipolar cells of the rat retina. J Neurophysiol 63:860876.

Kirsch J, Betz II (1993) Widespread expression of gephyrin, a putative glycine receptor-tubulin linker protein, in rat brain. Brain Res 621: $301-310$.

Kirsch J, Langosch D, Prior P, Littauer UZ, Schmitt B, Betz H (1991) The $93-\mathrm{kDa}$ glycine receptor-associated protein binds to tubulin. J Biol Chem 266:22242-22245.

Kirsch J, Malosio M-L, Wolters I, Betz H (1993a) Distribution of gephyrin transcripts in the adult and developing rat brain. Eur J Neurosci 5:1109-1117.

Kirsch J, Wolters I, Triller A, Betz H (1993b) Gephyrin antisense oligonucleotides prevent glycine receptor clustering in spinal neurons. Nature 366:745-748.

Kolb H (1979) The inner plexiform layer in the retina of the cat: electron microscopic observations. J Neurocytol 8:295-329.

Kolb H, West R (1977) Synaptic connections of the interplexiform cell in the retina of the cat. $J$ Neurocytol 6:155-170.

Kuhse J, Schmieden V, Betz H (1990a) Identification and functional expression of a novel ligand binding subunit of the inhibitory glycine receptor. J Biol Chem 265:22317-22320.

Kuhse J, Schmieden V, Betz H (1990b) A single amino acid exchange alters the pharmacology of neonatal rat glycine receptor subunit. Neuron 5:867-873.

Kuhse J, Kuryatov A, Maulet Y, Malosio M-L, Schmieden V, Betz H (1991) Alternative splicing generates two isoforms of the $\alpha 2$ subunit of the inhibitory glycine receptor. FEBS Lett 283:73-77.

Lambrecht H-G, Koch K-W (1991) A 26kd calcium binding protein from bovine rod outer segments as modulator of photoreceptor guanylate cyclase. EMBO J 10:793-798.

Lambrecht II-G, Koch K-W (1992) Recoverin, a novel calcium-binding protein from vertebrate photoreceptors. Biochim Biophys Acta 1160:63-66.

Langosch D, Becker C-M, Betz H (1990) The inhibitory glycine receptor: a ligand-gated chloride channel of the central nervous system. Eur J Biochem 194:1-8.

Linberg KA, Fisher SK (1986) An ultrastructural study of interplexiform cell synapses in the human retina. J Comp Neurol 243:561576.

Malosio M-L, Marquèze-Pouey B, Kuhse $J$, Betz H (1991a) Widespread expression of glycine receptor subunit mRNAs in the adult and developing rat brain. EMBO J 10:2401-2409.

Malosio M-L, Grenningloh G, Kuhse J, Schmieden V, Schmitt B, Prior $\mathrm{P}$, Betz H (1991b) Alternative splicing generates two variants of the $\alpha 1$ subunit of the inhibitory glycine receptor. J Biol Chem 266:20482053.

Marc RE (1989) The role of glycine in the mammalian retina. Prog Ret Res 8:67-107.

Marc RE, Liu W-LS (1985) [ $\left.{ }^{3} \mathrm{H}\right]$ Glycine-accumulating neurons of the human retina. J Comp Neurol 232:241-260.

Martin PR, Grünert U (1992) Spatial density and immunoreactivity of bipolar cells in the macaque monkey retina. J Comp Neurol 323 : 269-287.

Massey SC, Redburn DA (1987) Transmitter circuits in the vertebrate retina. Prog Neurobiol 28:55-96.
Milam AH, Dacey DM, Dizhoor AM (1993) Recoverin immunoreactivity in mammalian cone bipolar cells. Visual Neurosci 10:112.

Mitchell K, Spike RC, Todd AJ (1993) An immunocytochemical study of glycine receptor and GABA in laminae I-III of rat spinal dorsal horn. J Neurosci 13:2371-2381.

Müller F, Wässle H, Voigt T (1988) Pharmacological modulation of the rod pathway in the cat retina. J Neurophysiol 59:1657-1672

Naas E, Zilles K, Gnahn H, Betz H, Becker C-M, Schröder H (1991) Glycine receptor immunoreactivity in rat human cerebral cortex. Brain Res 561:139-146.

Negishi K, Kato S, Teranishi T (1988) Dopamine cells and rod bipolar cells contain protein kinase C-like immunoreactivity in some vertebrate retinas. Neurosci Lett 94:247-252.

Peichl L (1989) Alpha and delta ganglion cells in the rat retina. J Comp Neurol 286:120-139.

Pfeiffer F, Graham D, Betz H (1982) Purification by affinity chromatography of the glycine receptor of rat spinal cord. J Biol Chem 257:9389-9393.

Pfeiffer F, Simler R, Grenningloh G, Betz H (1984) Monoclonal antibodies and peptide mapping reveal structural similaritics bctween the subunits of the glycine receptor of rat spinal cord. Proc Natl Acad Sci USA 81:7224-7227.

Pourcho RG (1980) Uptake of $\left[{ }^{3} \mathrm{H}\right]$-glycine and $\left[{ }^{3} \mathrm{H}\right]-\mathrm{GABA}$ by amacrine cells in the cat retina. Brain Res 198:333-346.

Pourcho RG, Goebel DJ (1985a) A combined Golgi and autoradiographic study of $\left[{ }^{3} \mathrm{H}\right]$-glycine-accumulating amacrine cells in the cat retina. J Comp Neurol 233:473-480.

Pourcho RG, Goebel DJ (1985b) Immunocytochemical demonstration of glycine in retina. Brain Res 348:339-342.

Pourcho RG, Goebel DJ (1987a) A combined Golgi and autoradiographic study of $\left[{ }^{3} \mathrm{H}\right]$-glycine-accumulating cone bipolar cells in the cat retina. J Neurosci 7:1178-1188.

Pourcho RG, Goebel DJ (1987b) Visualization of endogenous glycine in cat retina: an immunocytochemical study with Fab fragments. J Neurosci 7:1189-1197.

Pourcho RG, Goebel DJ (1990) Autoradiographic and immunocytochemical studies of glycine-containing neurons in the retina. In: Glycine neurotransmission (Ottersen OP, Storm-Mathisen J, eds), pp 355-389. Chichester: Wiley.

Pourcho KG, Owczarzak MT (199la) Connectivity of glycine immunoreactive amacrine cells in the cat retina. J Comp Neurol 307: 549-561.

Pourcho RG, Owczarzak MT (199lb) Glycine receptor immunoreactivity is localized at amacrine synapses in cat retina. Vis Neurosci 7:611-618.

Schmieden V, Grenningloh G, Schofield PR, Betz H (1989) Functional expression in Xenopus oocytes of the strychnine binding $48 \mathrm{kd}$ subunit of the glycine receptor. EMBO J 8:695 700 .

Schmitt B, Knaus P, Becker C-M, Betz H (1987) The $M_{r} 93,000$ polypeptide of the postsynaptic glycine receptor complex is a peripheral membrane protein. Biochemistry 26:805-811.

Schröder S, Hoch W, Becker C-M, Grenningloh G, Betz H (1991) Mapping of antigenic epitopes on the $\alpha 1$ subunit of the inhibitory glycine receptor. Biochemistry 30:4247.

Seitanidou T, Triller A, Korn H (1988) Distribution of glycine receptors on the membrane of a central neuron: an immunoelectron microscopy study. J Neurosci 8:4319-4333.

Smiley JF, Yazulla S (1990) Glycinergic contacts in the outer plexiform layer of the Xenopus laevis retina characterized by antibodies to glycine, GABA and glycine receptors. J Comp Neurol 299:375-388.

Sontheimer H, Becker C-M, Pritchett D, Schofield P, Grenningloh G, Kettenmann H, Betz H, Seeburg P (1989) Functional chloridc channels by mammalian cell expression of rat glycine receptor subunit. Neuron 2:1491-1497.

Sterling $P$ (1983) Microcircuitry of the cat retina. Annu Rev Neurosci $6: 149-185$.

Stichel CC, Kägi U, Heizmann CW (1986) Parvalbumin in cat brain: isolation, characterization and localization. J Neurochem 47:46-53.

Strettoi E, Raviola E, Dacheux RF (1992) Synaptic connections of the narrow-field, bistratified rod amacrine cells (AII) in the rabbit retina. J Comp Neurol 325:152-168.

Suzuki S, Tachibana M, Kaneko A (1990) Effects of glycine and GABA on isolated hipolar cells of the mouse retina. J Physiol (Lond) 421: 645-662.

Triller A, Cluzeaud F, Pfeiffer F, Betz H, Korn H (1985) Distribution 
of glycine receptors at central synapses: an immunoelectron microscopy study. J Cell Biol 101:683-688.

Triller A. Cluzeaud F, Korn H (1987) Gamma-aminobutyric acidcontaining terminals can be apposed to glycine receptors at central synapses. J Cell Biol 104:947-956.

van den Pol AN, Gorcs T (1988) Glycine and glycine receptor immunoreactivity in brain and spinal cord. J Neurosci 8:472-492.

Vaney DI (1990) The mosaic of amacrine cells in the mammalian retina. Prog Ret Res 9:49-100.

Wässle H, Boycott BB (1991) Functional architecture of the mammalian retina. Physiol Rev 71:447-480.

Wässle H, Schäfer-Trenkler L, Voigt 7 (1986) Analysis of a glycinergic inhibitory pathway in the cat retina. J Neurosci 6:594-604.

Wässle $H$, Yamashita M, Greferath U, Grünert U, Müller F (1991) The rod bipolar cell of the mammalian retina. Vis Neurosci 7:99112

Wässle H, Grünert U, Röhrenbeck J (1993) Immunocytochemical staining of AII amacrine cells in the rat retina with antibodies against parvalbumin. J Comp Neurol 332:407-420.

Wenthold RJ, Parakkal MH, Oberdorfer MD, Altschuler RA (1988) Glycine receptor immunoreactivity in the ventral cochlear nucleus of the guinea pig. J Comp Neurol 276:423-435.

Yazulla S, Studholme KM (1991a) Glycinergic interplexiform cells make synaptic contact with amacrine cell bodies in goldfish retina. J Comp Neurol 310:1-10.

Yazulla S, Studholme KM (1991b) Glycine-receptor immunoreactivity in retinal bipolar cells is postsynaptic to glycinergic and GABAergic amacrine cell synapses. J Comp Neurol 310:1 1-20.

Zucker CL, Ehinger B (1992) Heterogeneity of receptor immunoreactivity at synapses of glycine-utilizing neurons. Proc R Soc Lond [Biol] 249:89-94.

Zucker CL, Ehinger B (1993) Synaptic connections involving immunoreactive glycine receptors in the turtle retina. Vis Neurosci 10 907-914. 